\title{
Hominin Dispersal and Settlement East of Huxley's Line
}

\author{
The Role of Sea Level Changes, Island Size, and Subsistence Behavior
}

\author{
by Sue O’Connor, Julien Louys, Shimona Kealy, \\ and Sofía C. Samper Carro
}

\begin{abstract}
The thousands of islands east of Huxley's Line have never formed a single land mass or been connected to Sunda or Sahul. The earliest records of hominins in this area are stone tools recovered from Pleistocene deposits on Flores and Sulawesi. Subsistence by these hominins as well as the later subsistence patterns exhibited by Homo floresiensis suggest that exploitation of marine resources was, at best, rare and opportunistic. Likewise, the fragmentary hominin remains recovered from Late Pleistocene deposits from Callao Cave in the Philippines exploited large game at the expense of marine resources. In contrast, the earliest zooarchaeological records of modern humans are dominated by marine fish and shellfish and include the earliest evidence of pelagic fishing using shell tools, implying complex fishcapture technology. Pleistocene lithic assemblages on these islands are unspecialized, indicating reduction of predominantly locally available stone to produce flakes and irregularly retouched pieces. By the terminal Pleistocene, records of human subsistence on very small islands indicate almost total reliance on marine foods for protein. We propose that strong links exist between subsistence strategies and dispersal throughout Wallacea, with subsistence strategies available to pre-sapiens hominins in the region being a major limiting factor in their dispersal.
\end{abstract}

The movement of hominins through island Southeast Asia and into Australia is the last leg of several migration events that began in Africa thousands of years before. Debate over the route(s) taken by these hominins is ongoing, with various hypotheses supporting an inland or coastal route (Erlandson and Braje 2015; Groucutt et al. 2015; Reyes-Centeno et al. 2014 and other papers in this volume). Regardless of route choice, however, once hominins arrived at Huxley's Line (see

Sue O'Connor is Laureate Professor in the Archaeology and Natural History Department of the College of Asia and the Pacific at the Australian National University (Building 9, Fellows Road, Canberra, Australian Capital Territory 0200, Australia [sue.oconnor@anu.edu .au]). Julien Louys is a Postdoctoral Research Fellow in the Archaeology and Natural History Department of the College of Asia and the Pacific at the Australian National University (Building 9, Fellows Road, Canberra, Australian Captial Territory 0200, Australia [julien .louys@anu.edu.au]). Shimona Kealy is a PhD Candidate in the Archaeology and Natural History Department of the College of Asia and the Pacific at the Australian National University (Building 9, Fellows Road, Canberra, Australian Capital Territory 0200, Australia [shimona.kealy@anu.edu.au]).Sofía C. Samper Carro is a Lecturer in the School of Archaeology and Anthropology of the College of Arts and Social Sciences of the Australian National University (14 Ellery Crescent, Canberra, Australian Capital Territory 0200, Australia [sofia .samper@anu.edu.au]). This paper was submitted 12 X 16, accepted 23 VI 17, and electronically published 8 XI 17. fig. 1), earlier Pleistocene hominins would have had to undertake sea journeys to reach Sulawesi and Flores, and late Pleistocene Homo sapiens would have had to undertake even longer sea crossings to arrive on Sahul.

Dispersals by the earliest hominins in the region are likely to have been incidental and possibly enabled by natural rafts carried by oceanic currents and perhaps tsunamis (Dennell et al. 2014). Irrespective of dispersal mechanism, successful colonization of an island requires that subsistence needs are met, although this aspect does not appear to have been given as much consideration in the migration of pre-sapiens east of Huxley's Line as in the migration of $H$. sapiens. For example, Allen and O'Connell (2003, 2008) and O'Connell and Allen (2007, 2012) applied the tenets of optimal foraging to predict the pattern of human dispersal to Australia, arguing that the movement of humans through Wallacea was driven by a negative change in resource availability, which was driven, in turn, by fluctuations in sea level that encouraged relocation to more optimal areas (i.e., new islands). However, hypotheses such as these have yet to be convincingly tested due to limited archaeological records in the region (Anderson 2017; Kealy, Louys, and O'Connor 2016).

Sea level changes also affect island size and intervisibility between islands. The lower sea levels produced during glacials are generally thought to have been optimal for migration in the Wallacean archipelago, because the shorter distances between 


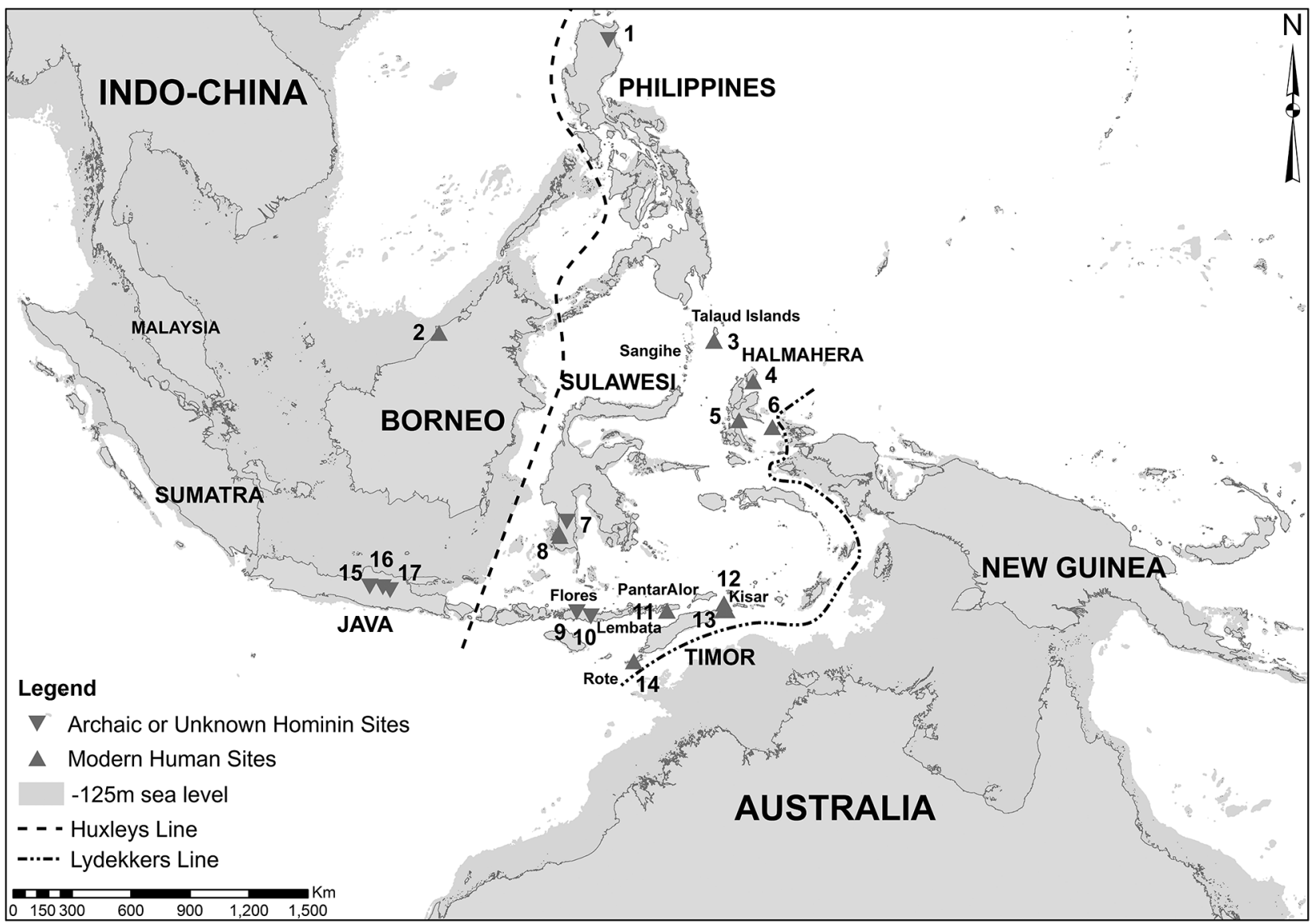

Figure 1. Map of island Southeast Asia showing sites mentioned in text. Downward-pointing triangles indicate sites associated with archaic or "unknown" hominin localities, and upward-pointing triangles indicate sites associated with modern humans. A color version of this figure is available online.

islands would presumably have made sea crossings easier (Birdsell 1977; Kealy, Louys, and O’Connor 2016, 2017). However, some researchers (Chappell 1993; O’Connell, Allen, and Hawkes 2010; O'Connor and Chappell 2003) have argued that rising sea levels after $55 \mathrm{ka}$ might have encouraged and even facilitated colonization. The small number of Pleistocene archaeological sites in the region makes it hard to test competing migration hypotheses as they relate to timing and sea level changes (Anderson 2017; Kealy, Louys, and O'Connor 2016).

Although Pleistocene archaeological records are rare in Wallacea, the situation is beginning to improve, with new sites recorded and sequences analyzed in the past few years (O'Connor 2007; O'Connor et al. 2010; Pawlik et al. 2015; Robles et al. 2015; Samper Carro et al. 2016; Szabó, Brumm, and Bellwood 2007). In particular, the zooarchaeological records produced on several Wallacean islands allow for the examination of some of the factors that may have been influential in facilitating dispersals in the region. Here, we review these records, paying particular attention to the environmental limitations of small oceanic islands for successful colonization. We examine the probable subsistence behavior and distribution of the first hominins in the region and contrast these with $H$. sapiens in the later Pleistocene in the context of sea level changes and island size during the likely periods of movement.

\section{Bathymetry and Sea Level Changes at the Regional Scale}

The Pleistocene saw enormous changes in the spatial environment of the Wallacean Archipelago (Kealy, Louys, and O'Connor 2017). Driven largely by dramatic changes in climate, with secondary tectonic influences, the islands of Wallacea have experienced a combination of emerging and subsiding phenomena, enlargements and shrinkages, and joining and separation that have affected the dynamics of this area. Such changes had a major impact on the island ecosystems as well as the most parsimonious pathways for human movement between islands (Kealy, Louys, and O'Connor 2016).

To date, archaeological investigations in the Wallacean Archipelago have been patchy, with most research focused on the larger islands of Sulawesi, Flores, and Timor. Logically, the larger Wallacean islands would have presented more diverse 
and reliable habitats for sustaining genetically viable populations. In the past 100,000 years, sea levels in Wallacea have fluctuated below present-day heights, with drops of up to $135 \mathrm{~m}$ during the last glacial maximum (LGM; Lambeck and Chappell 2001). Studies in Timor and other islands also suggest the region has experienced a significant degree of tectonic uplift during this time, although neither the geographic extent nor the results of the research are consistent throughout Wallacea (Chappell and Veeh 1978; Cox 2009; Hantoro et al. 1994; Jouannic et al. 1988; Major et al. 2013; Nexer et al. 2015; Pirazzoli et al. 1993; Sumosusastro et al. 1989). A summary of these studies and the uplift rates recorded therein indicates a dearth of uplift research in regions such as the Halmahera Archipelago (Kealy, Louys, and O'Connor 2017, their table 1); in contrast, Timor-Leste has had numerous studies producing uplift rates that range from 0.1 to $0.6 \mathrm{~m} / \mathrm{kyr}$.

The consideration of an uplift variable in paleogeographic reconstructions is important for avoiding overestimations of island size and connectivity at times of lower sea levels. The lack of comprehensive uplift measurements throughout Wallacea means an accurate model of island uplift is currently unavailable; however, an average rate, calculated from islands with known uplift data, provides one alternative (Kealy, Louys, and O'Connor 2017). We acknowledge that this is an average calculated from data with significant variability; however, we consider a conservative estimate on past island extent prefer- able to ignoring uplift entirely. Thus, we adjusted the Lambeck and Chappell (2001) sea level curve to account for an average uplift rate of $0.5 \mathrm{~m} / \mathrm{kyr}$ (Kealy, Louys, and O'Connor 2017) for the past 100,000 years (fig. 2). As the majority of the uplift rates are from Quaternary (and largely Holocene) limestone (Chappell and Veeh 1978; Cox 2009; Hantoro et al. 1994; Major et al. 2013; Sumosusastro et al. 1989), any minor changes in uplift rate over this time will also be averaged out across the 100-kyr sea level curve. When sea level fluctuations are adjusted for this uplift rate, the sea level trend remains the same; however, the relative drop in sea level as measured from the shoreline decreases over time (fig. 2). This is an important consideration for paleo-shoreline reconstructions, particularly those concerning the periods hypothesized for initial human colonization of Wallacea and Sahul (fig. 3). The reconstructions presented here are based on the most recent bathymetric chart of Wallacea (obtained from the General Bathymetric Chart of the Oceans data set, downloaded from http://www.gebco.net; Smith and Sandwell 1997) and the adjusted sea levels from figure 2 . The reconstruction does not take sedimentation and erosion processes into account because of the unavailability of such data. Hindcasting these changes in sea level and uplift to the period of earliest hominin movements at $\sim 1 \mathrm{Ma}$ is not realistic. Nevertheless, while lowered sea levels created larger landmasses and allowed for some Wallacean islands to be connected, many of the volcanic islands in this region - for example, Pantar-were

Table 1. Archaeological sites pertaining to hominin dispersal and settlement east of Huxley's Line

\begin{tabular}{|c|c|c|}
\hline Site & Published date ${ }^{\mathrm{a}}$ & Reference(s) \\
\hline Callao Cave & $66.7 \pm 1 \mathrm{ka}$ to Late Holocene & Mijares et al. 2010 \\
\hline Niah Cave & $\sim 50 \mathrm{ka}(47,170-50,000 \mathrm{ka})$ to Late Holocene & Higham et al. 2016 \\
\hline Liang Sarru & $35,034-33,864,22,628-21,941$ and Holocene & Ono, Soegondho, and Yoneda 2009 \\
\hline Daeo 2 & $16,767-15,889$ to Late Holocene & Bellwood et al. 1998 \\
\hline Siti Nafisah & $5,572-5,296$ to Late Holocene & Bellwood et al. 1998 \\
\hline Golo Cave & $36,350-35,001$ to Late Holocene & Bellwood et al. 1998 \\
\hline Talepu & $194-118 \mathrm{ka}$ to after $103 \pm 9 \mathrm{ka}$ & van den Bergh et al. $2016 b$ \\
\hline $\begin{array}{l}\text { Leang Timpuseng } \\
\text { and Maros region }\end{array}$ & $40.70+0.87 /-0.84$ ka to Late Holocene & Aubert et al. 2014 \\
\hline Liang Bua & $\begin{array}{l}193 \pm 33 \mathrm{ka} \text { (initial hominin occupation), } 49.6 \pm 0.5 \mathrm{ka} \\
\text { (Homo floresiensis terminal date), } 19.2 \mathrm{ka} \text { to Late } \\
\text { Holocene (modern humans) }\end{array}$ & Sutikna et al. 2016; Westaway et al. 2007 \\
\hline Liang Bawah & 238-181 ka to Late Holocene & Gagan et al. 2015 \\
\hline Mata Menge & $810 \pm 40 \mathrm{ka}$ to $650 \pm 20 \mathrm{ka}$ & Brumm et al. 2016 \\
\hline Tangi Talo & No in situ artifacts; fauna dated to $900 \pm 70 \mathrm{ka}$ & Aziz et al. 2009; Morwood et al. 1998 \\
\hline Tron Bon Lei & $21,000-20,560$ to $3,195-3,010$ & $\begin{array}{l}\text { O'Connor et al., forthcoming } b \text {; Samper } \\
\text { Carro, Louys, and O'Connor } 2017\end{array}$ \\
\hline Here Sorot Entapa & $15,338-15,091$ to Late Holocene & New data, this article \\
\hline Jerimalai & $43,002-41,313$ to Late Holocene & O’Connor 2007 \\
\hline Lene Hara & $42,454 \pm 450$ to Late Holocene & O'Connor, Allen, and Hawkes 2010 \\
\hline Matja Kuru 2 & $36,307-35,031$ to Late Holocene & O’Connor, Robertson, and Aplin 2014 \\
\hline Lua Meko & $28,603-27,676$ to Late Holocene & Mahirta 2009 \\
\hline Sangiran Dome & $1.66 \pm 0.04 \mathrm{Ma}$ to Middle Pleistocene & $\begin{array}{l}\text { Bouteaux et al. 2007; Sémah, Saleki, and } \\
\text { Falguéres } 2000\end{array}$ \\
\hline Ngebung & $800 \mathrm{ka}$ & Bouteaux and Moigne 2010 \\
\hline Trinil & $540 \pm 100 \mathrm{ka}$ to $430 \pm 50 \mathrm{ka}$ & Joordens et al. 2015 \\
\hline Kedung Brubus & $700-800 \mathrm{ka}$ & Storm 2012; van den Bergh et al. 1996 \\
\hline
\end{tabular}

${ }^{\text {a }}$ Ages are the published calibrated ${ }^{14} \mathrm{C}$, electron spin resonance, and U-series dates. 
Sea-Level over time adjusted for $0.5 \mathrm{~m} / \mathrm{kyr}$

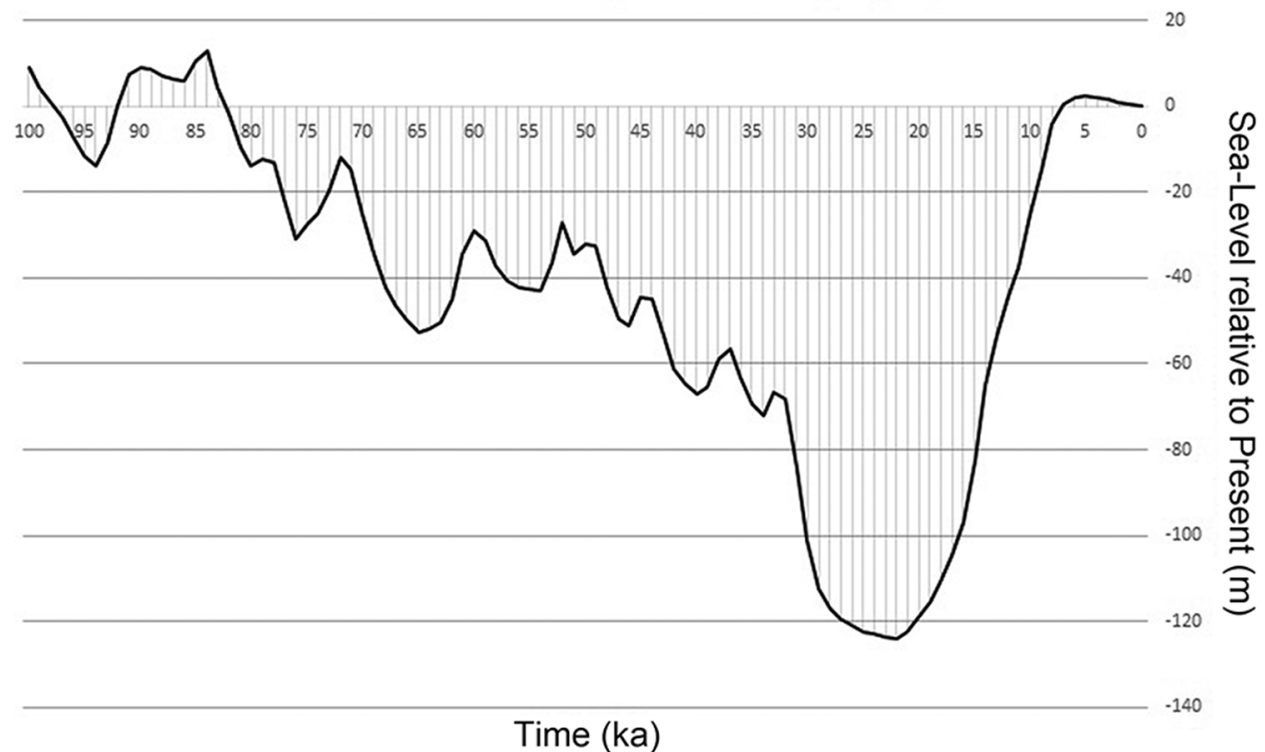

Figure 2. Sea level for the past $100 \mathrm{kyr}$ (Lambeck and Chappell 2001) adjusted for $0.5 \mathrm{~m} / \mathrm{kyr}$ uplift as calculated in Kealy, Louys, and O'Connor (2017, their table 1).

smaller than today, because they have been undergoing active formation since that time.

\section{Subsistence and Dispersal of Early Hominins in Asia}

When hominins began to introduce large amounts of animal protein into their diets through access and processing of carcasses is not known; however, by at least $2 \mathrm{Ma}$, hominins (likely Homo erectus) were practicing persistent carnivory in East Africa (Ferraro et al. 2013; Lemorini et al. 2014; Parkinson 2013; Plummer 2004), and in the Early Pleistocene, primary access of fleshed carcasses by hominins is recorded at several sites (Domínguez-Rodrigo, Bunn, and Yravedra 2014; Organista et al. 2016). Organista et al. (2016:620-621) suggest that the hominin group responsible for the dense concentration of megafauna at Bell Korongo, Olduvai Gorge, exhibited "a degree of cooperative behaviour that required a capacity for strategy, organization, communication, and physical effort." Such traits were no doubt useful in the initial dispersal of hominins outside of Africa and into Asia, although, as many other mammalian families attest, such traits are not absolutely essential for widespread migrations between Asia and Africa (e.g., O’Regan et al. 2011).

In Asia, subsistence behavior of Early to Middle Pleistocene hominins is poorly known, due in large part to a dearth of zooarchaeological evidence (Dennell 2015). Whether this dearth represents a genuine lack of evidence or reflects the much smaller volume of zooarchaeological studies in the region is unknown, but certainly taphonomic studies of faunal remains associated with hominins in the region are rare. Boaz et al. (2004) has suggested that Chinese $H$. erectus scavenged remains from a hyena den in Locality 1 of Zhoukoudian. A more recent taphonomic analysis of cervid remains from layer 3 of Zhoukoudian found no evidence of anthropogenic modifications (Zhang et al. 2015). Likewise, visual examination of a subset of faunal remains from Gongwangling found no evidence of cut marks on bones (Louys et al. 2009). Hominins likely had a role in the accumulation of large-bodied mammal remains in Panxian Dadong; however, whether this was primarily from scavenging or from hunting activities remains unresolved (Schepartz, Stoutamire, and Bekken 2005; Schepartz et al. 2003). Findings from Ubeidiya tentatively suggest some evidence for butchery and hunting of medium-size game (Gaudzinski 2004).

In Java, Storm (2012) has suggested that H. erectus occupied a largely carnivorous niche on the basis of the number of identified specimens and minimum number of individuals from Dubois legacy collections (specifically, Kedung Brubus and Trinil; see table 1). Storm (2012) was understandably cautious in his conclusions; a visual examination of these collections by one of the authors (J. Louys) in 2006 revealed no marks that could be unambiguously attributed to Pleistocene hominins. Likewise, Bouteaux et al. (2007) found no evidence of anthropogenic modifications on remains from several Sangiran Dome localities (Tanjung, Sendang Busik, Ngrejeng Plupuh, Grogol Plupuh, and Bukuran; table 1). The lack of obvious marks on these bones does not necessarily mean that Early and Middle Pleistocene hominins did not have access to or consume large and medium-size game. They may instead be a result of processing with tools made of materials other than stone that leave less obvious signatures on the bone, such as bamboo (West and 


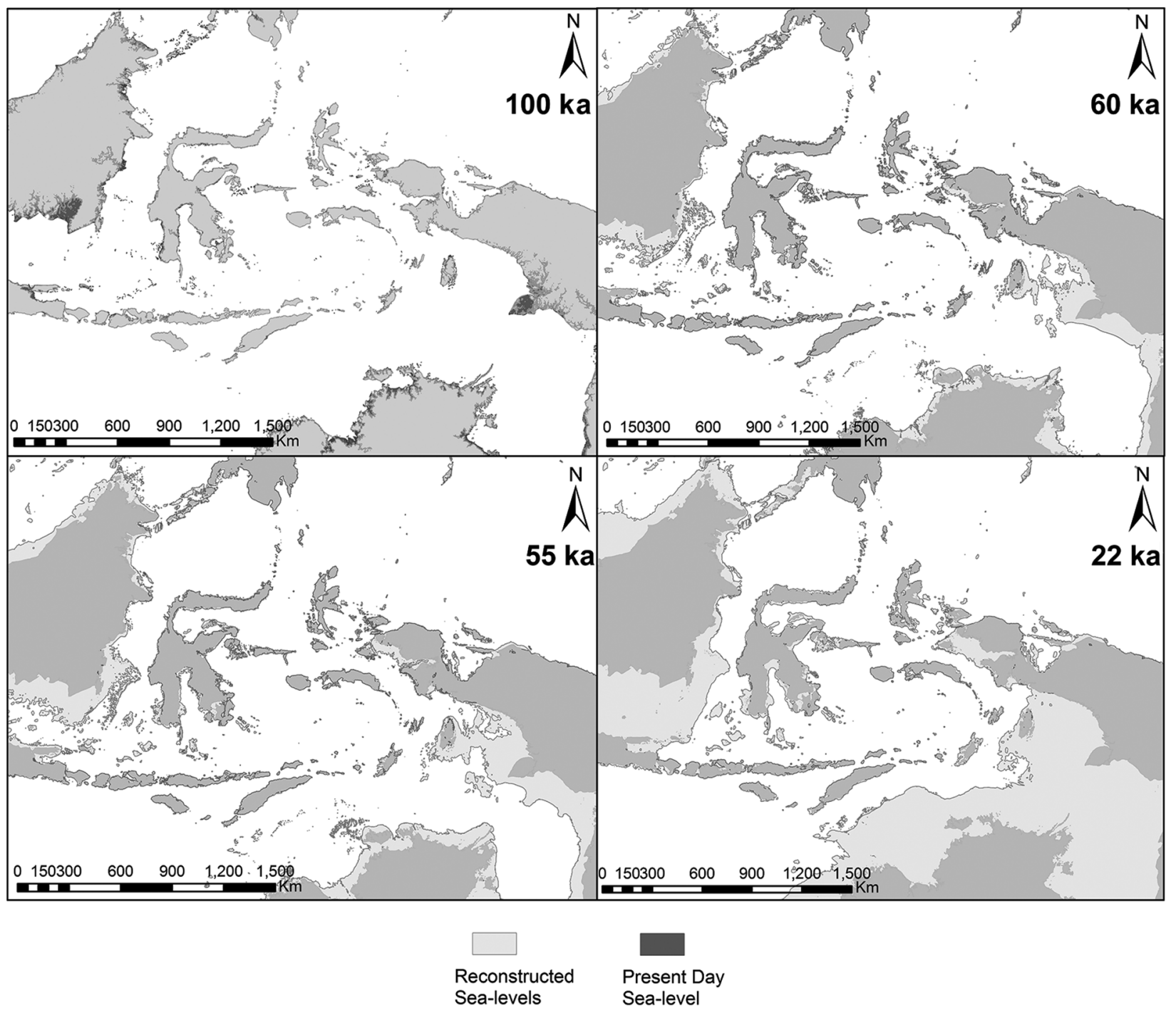

Figure 3. Palaeo-shoreline reconstructions for Wallacea and neighbors for $100 \mathrm{ka}, 60 \mathrm{ka}, 55 \mathrm{ka}$, and $22 \mathrm{ka}$. Modeled using the General Bathymetric Chart of the Oceans 30 arc-second bathometry chart (Smith and Sandwell 1997). Sea levels are based on the adjusted curve in figure 2. A color version of this figure is available online.

Louys 2007) or shells (Choi and Driwantoro 2007), as well as the depositional setting of the assemblages in question, minimizing the potential for hominin actions on faunal remains. For example, Zhoukoudian is primarily interpreted as a hyena den, and the aforementioned Sangiran Dome deposits represent natural fluvial accumulations (Bouteaux et al. 2007), neither of which might attract hominin attention.

Although rare, direct evidence of processing of animal carcasses by Asian $H$. erectus does exist. Choi and Driwantoro (2007) report likely shell tool cut marks on bovid (Bos species) remains from Bukuran and Sangiran, and Bouteaux and Moigne (2010) reported cut marks and percussion damage on long bones belonging to Axis species and Duboisia species recovered from Ngebung 2 (table 1). Despite limited direct evidence, the use and processing of large and medium-size game by Pleistocene Asian hominins is inferred by most researchers through extension of the realized niche that $H$. erectus occupied in Africa (e.g., Bouteaux et al. 2007; Dennell 2014; Larick and Ciochon 2015). This represents a reasonable inference.

Evidence of the use of marine resources for subsistence by $H$. erectus, however, is even more circumstantial. Freshwater shellfish were known to $H$. erectus populations, and the shells were used as tools and perhaps even for decorative art (Choi and Driwantoro 2007; Joordens et al. 2015). Evidence of coastal, lacustrine, swamp forest, lagoon, and marshy environments present during the deposition of the Trinil HK assemblage demonstrates that aquatic resources were present at the same time as $H$. erectus in Middle Pleistocene Java (Joordens et al. 2009). Likewise, the presence of crocodile and fish remains in Ngebung is suggestive of exploitation of aquatic resources 
(Moigne et al. 2004). However, direct evidence of the exploitation of marine resources by Early and Middle Pleistocene hominins has yet to be shown. No doubt Pleistocene hominins were opportunistic omnivores and would not have refrained from using any resources available to them. Nevertheless, on the basis of the environmental contexts in which they have been recovered, it is probable that pre-sapiens hominin populations were constrained to environments where fresh water, animals, and plants were plentiful (Dennell 2014), and it appears that aquatic resources constituted only a minor element of protein intake.

East of Huxley's Line, Early Pleistocene hominins are restricted to the islands of Flores. There, the Early Pleistocene vertebrate fauna population was clearly impoverished (Dennell et al. 2014; Meijer et al. 2010), particularly in comparison with the faunal records of similar periods on Java and China. Only a dwarf stegodon (Stegodon sondaari), the Komodo dragon (Varanus komodoensis), and a giant tortoise (Geochelone species) are known from the site of Tangi Talo (Brumm et al. 2010; Meijer et al. 2010), dated to approximately $0.9 \mathrm{Ma}$ (Aziz et al. 2009; Morwood et al. 1998). After the deposition of Tangi Talo, a turnover was recorded at Mata Menge and similarly aged sites, and a new, larger species of stegodon (Stegodon florensis), a rat (Hooijeromys nusatenggara), the Komodo dragon, and a tool-making hominin are recorded (Brumm et al. 2010, 2016; Meijer et al. 2010; van den Bergh et al. 2016a; see table 1). The habitat at Mata Menge has been reconstructed as one composed of open, savannah-like grasslands with a wetland component (Brumm et al. 2016). The specific identity of the small-bodied hominin responsible for the stone tools on Mata Menge is not known (van den Bergh et al. 2016a); however, recent analyses have suggested $H$. erectus was the likely ancestor of this hominin (as well as the later Homo floresiensis; Kaifu et al. 2015; van den Bergh et al. 2016a; van Heteren 2012; van Heteren and de Vos 2007; van Heteren and Sankhyan 2009), and its dispersal from Java in the Early Pleistocene is not contradicted by paleobiogeographical data (Dennell et al. 2014). In addition to the terrestrial fauna and associated archaeology, crocodiles, ducks, swans, and abundant freshwater mollusc species were recovered from Mata Menge (Brumm et al. 2016; van den Bergh et al. 2009a). Whether these were natural or anthropogenic is not known, although the age profile of the stegodon assemblage is consistent with a natural mass death event (Brumm et al. 2016). This age profile contrasts with both the later Liang Bua and the Middle Pleistocene Panxian Dadong stegodon assemblages, which are dominated by young individuals and thought to have been, at least in part, accumulated by hominins (table 1; Brumm et al. 2016; Schepartz, Stoutamire, and Bekken 2005).

A much more nuanced and detailed record of faunalhominin associations is present in the $H$. floresiensis-bearing Liang Bua deposits. There, a long sequence of faunal and archaeological records are dated to earlier than ca. $50 \mathrm{ka}$ (Sutikna et al.2016), suggesting that the dominant animal resources used by $H$. floresiensis were potentially stegodons, Komodo dragons, monitor lizards, and a variety of birds and rats (van den Bergh et al. 2009b). Most significantly, although small amounts of terrestrial gastropods were recovered in the excavations, molluscs and other aquatic fauna are completely absent from deposits dating to earlier than $11 \mathrm{ka}$; deposits from $11 \mathrm{ka}$ and after are accepted to have been accumulated by Homo sapiens, which suggests that such resources played no part in the subsistence strategies of $H$. floresiensis (Szabó and Amesbury 2011). This is consistent with the (admittedly sparse) evidence of subsistence strategies of hominins across Asia. Overall, these records suggest that $H$. floresiensis and its ancestor, probably $H$. erectus, made no use of aquatic resources on Flores and required access to large- and medium-bodied vertebrate remains for survival.

Sulawesi has often been cited as the origin of $H$. floresiensis populations (e.g., Morwood and Oosterzee 2007), and recent lithic finds from Talepu in the Walanae Valley on this island are consistent with early hominin colonization of Wallacea (van den Bergh et al. 2016a; table 1). Although the stone tools from Talepu in Sulawesi cannot be tied to any particular hominin species, van den Bergh et al. (2016b) make a case that they could have been made by archaic Homo. As on Flores, the fauna recovered in association with the tools are medium- to largebodied terrestrial species, namely buffalo, stegodon, and a large extinct endemic pig (Bubalus, Stegodon, and Celebochoerus), and could thus have been used by hominins for subsistence. In addition to these species, Sulawesi also hosts seven extant species of macaque, the Sulawesi babirusa (Babyrousa celebensis), the Sulawesi warty pig (Sus celebensis), and two species of anoa (Bubalus depressicornis and Bubalus quarlesi) that would have potentially been available to early hominin scavengers or hunters, although these species have thus far not been recovered from Early to Middle Pleistocene archaeological excavations.

In the Philippines, a hominin fossil from Callao Cave in Luzon has not yet been identified to species. It was referred to Homo species (Mijares et al. 2010) and favorably compared with small-bodied Homo species, such as Homo habilis and H. floresiensis (Larick and Ciochon 2015), although provisionally attributed to $H$. sapiens by Mijares et al. (2010). It has a minimum age of around $50 \mathrm{kyr}$ (Grün et al. 2014) and is found in association with several large taxa: the native brown deer (Cervus mariannus), the Philippine warty pig (Sus philippensis), and an extinct bovid (Piper and Mijares 2007). The brown deer dominates the assemblage, with more than $90 \%$ of the identifiable bone fragments assigned to cervid. Interestingly, although no stone tools have been recovered from this level at Callao Cave, cut marks are present on deer remains, implying the use of perishable tools by this hominin (Mijares et al. 2010). Only miniscule aquatic remains have been recovered from the cave (Piper and Mijares 2007), which suggests that these did not constitute a part of subsistence behavior at this site (see table 1).

With so few Early to Middle Pleistocene hominin sites east of Huxley's Line, it is difficult to be confident about the realized niche of pre-sapiens hominins on Wallacean islands. The African record gives every reason to expect that $H$. erectus was a resourceful and opportunistic species, making use of whatever 
resources were on hand. This is reflected, albeit less clearly, in the Asian record. Regardless, however, it would appear that this species had a reliance on sources of large- or mediumbodied carcasses to survive, and we argue that these requirements help explain the restricted distribution of hominins in Wallacea. Homo floresiensis and the new records from Sulawesi (van den Bergh et al. 2016b) demonstrate that water crossings were not a barrier to hominin dispersals, even if such dispersals were unintentional and subject to prevailing oceanic conditions (Dennell et al. 2014). However, successful colonization of islands requires not only travel but that the subsistence requirements of the colonizing species are met. We argue that, for early hominins, this would have required access to adequate terrestrial faunal resources and that complete or near-complete reliance on aquatic resources required technological and behavioral innovations that were beyond the reach of pre-sapiens hominins in Wallacea.

\section{Zooarchaeological Records and Subsistence Strategies of Homo sapiens in Wallacea}

There are few sites in Sunda that inform on the subsistence of $H$. sapiens at the time of first modern human maritime dispersal. Niah Cave in Sarawak, with a record spanning at least 50,000 years (Higham et al. 2016), perhaps gives us the clearest picture of the eclectic and flexible nature of modern human economic activities in Sunda before their arrival in Wallacea. At the time of the earliest recorded occupation, Niah was about $30 \mathrm{~km}$ from the Pleistocene coastline, and the people living there pursued diverse subsistence strategies, exploiting resources from the forests surrounding the caves and a range of freshwater environments. Pig seems to have been a major prey (Sus barbatus), but a wide range of species were exploited, including langurs, macaques, porcupines, monitors and smaller lizards, snakes, birds, and bats as well as molluscs and fish (Piper and Rabett 2017). Niah continued to be used during the LGM when lowered temperatures and a downward migration of the montane forest are indicated by the presence of the lesser gymnure (Hylomys suillus) and the ferret badger (Helictis orientalis), species that are today restricted to the highlands of Mount Kinabalu (Cranbrook 2000). As sea level rose after the LGM and coastal estuaries began to establish, there is evidence for an increasing focus on estuarine resources. The Niah fish assemblage includes large individuals from freshwater streams and estuaries, which indicates the use of nets or spears in their capture (Barker et al. 2007). Niah is also unique in preserving evidence of Pleistocene plant exploitation and includes fragments of fruits, nuts, and parenchyma (Barton, Paz, and Carlos 2017; Paz 2005), showing that "rainforest tuberous plants such as aroids, taro, yam, and sago palm" (Barker 2005:97; Barton 2005) were collected. Interestingly, many of the tubers required multistage processing to render them safely edible, demonstrating that early modern humans west of Huxley's Line possessed an advanced knowledge of plants, at least some of which would be familiar east of Huxley's Line.
Sulawesi, the largest of the Wallacean islands, was first occupied by modern humans by at least $\sim 40 \mathrm{ka}$ (Aubert et al. 2014). The earliest archaeological records on this island thought to be definitely attributable to H. sapiens are in South Sulawesi in the limestone karst near the modern city of Maros (table 1). Simons and Bulbeck (2004) show that, in the earliest period of modern human occupation, hunting focused on the endemic suids Sus celebensis and Babyrusa but included Anoa species as well as an extensive range of medium-size to small mammals (Simons and Bulbeck 2004). Interestingly, the South Sulawesi sites have no evidence for maritime resources use, but this may be due to transport distance, because at the time of earliest settlement, the Pleistocene shore would have been approximately 60-80 km away.

The Talaud-Sangihe Archipelago, lying between Mindanao and North Sulawesi, is of particular interest because it comprises 77 tiny and remote islands with little in the way of terrestrial faunal resources. Despite intensive coastal survey of a number of islands in this group, the only Pleistocene-aged site discovered in the Talauds to date is Liang Sarru shelter on Salibabu, which today is only $\sim 100 \mathrm{~km}^{2}$. Liang Sarru has evidence of episodic use in the Pleistocene between $\sim 35$ and $32 \mathrm{ka}$ and again between 22 and $17 \mathrm{ka}$, after which it appears to have remained unoccupied until the Holocene (table 1; Ono, Soegondho, and Yoneda 2009; Tanudirjo 2001). There is currently no archaeological evidence that the Talaud group acted as a stepping stone for colonization from the Philippines to Sulawesi, because the Liang Sarru sequence postdates initial modern human settlement in Sulawesi (Aubert 2014; Ono, Soegondho, and Yoneda 2009), and commensal rodent genetics suggest colonization of Talaud by agriculturalists from the south (Louys et al., forthcoming). While fossils of Stegodon are known from the Sangihe group, and bats, rats, birds, and marine vertebrates occur in the extant fauna, the Pleistocene occupation levels of Liang Sarru consist entirely of marine shellfish and a few urchin remains. The complete lack of Pleistocene vertebrate fossils from the Talaud Islands is puzzling. Poor preservation is unlikely to be the explanation, because marine shells are abundant and would have assisted the preservation of bone if it was deposited. While the lack of vertebrate fauna may be an effect of small sample size, exploration and excavation has been more intensive here than in many islands of the other Wallacean groups. It seems possible that the initial phase of settlement of the Sangihe-Talaud Islands comprised fleeting opportunistic visits by small, highly mobile groups of mariners coming to exploit seasonal island resources. Alternatively, perhaps the Liang Sarru sequence records an early "Robinson Crusoe" settlement that was ultimately unsuccessful (Leppard 2015; Leppard and Runnels 2017), and thereafter the islands remained unoccupied until about 22 ka when, due to the lowered sea levels of the LGM, individual islands of the Talaud group were connected to form a single megaisland incorporating the current islands of Karakelong, Salibabu, Kabaruan, and Sara. The Talaud mega-island reached between $1654.4 \mathrm{~km}^{2}$ (calculated with average Wallacan uplift of 
$0.5 \mathrm{~m} / \mathrm{kyr}$ ) and $1693.9 \mathrm{~km}^{2}$ (excluding uplift; fig. 4). Occupation of Liang Sarru during this phase appears to have been intensive but again short lived, lasting only until the end of the LGM $\sim 17 \mathrm{ka}$. The subsistence record during this phase is also solely shellfish, but stone artefacts are significantly more abundant, perhaps indicating a larger population or more regular use of the cave. Except in terms of total numbers, the stone artefact assemblage has been characterized as changing little through time. The earliest and LGM assemblages include low numbers of retouched flakes, some of which are classified as concave and convex scrapers with steep working edges suitable for wood working (Ono, Soegondho, and Yoneda 2009; Tanudirjo 2001:239-247).

Golo Cave on Gebe Island in northern Maluku has parallels with Liang Sarru. Golo was occupied by $\sim 36$ ka (table 1; Bellwood et al. 1998). At this time, Gebe Island was merged with neighbouring $\mathrm{Yu}, \mathrm{Fau}$, and Uta islands, forming a single landmass of between $644.30 \mathrm{~km}^{2}$ (using average $0.5 \mathrm{~m} / \mathrm{kyr}$ uplift) and $724.09 \mathrm{~km}^{2}$ (excluding uplift; fig. 5). Golo contains no subsistence evidence in the Pleistocene levels aside from marine shellfish (Bellwood et al. 1998:239). These comprise predominantly upper intertidal species dominated by a variety of limpets and small gastropods (Nerita species and Thais species) as well as barnacles (arthropods), some oysters, and carnivorous gastropods from Muricidae, which Szabó and Amesbury (2011:12) believe indicate foraging at local oyster beds. The Pleistocene horizons at Golo Cave contain few stone artefacts. The lithic assemblage includes a mere 51 stone artefacts made on a variety of metavolcanic rocks and comprises flake shatter, simple unretouched flakes, undiagnostic fragments, three cores, and a hammerstone. No retouched pieces were identified. However, flaked Turbo marmoratus opercula occur, and flakes of this dense shell may have substituted for flaked stone (Szabó, Brumm, and Bellwood 2007).

At $\sim 8 \mathrm{ka}$, Golo sees the first appearance of vertebrate fauna: bones of a now extinct Dorcopsis wallaby (Bellwood et al. 1998: 251-253; Flannery et al. 1998), a cuscus (Phalanger alexandrae) that still occurs on the island today (Flannery and Boeadi 1995), and a small quantity of reptile, bird, and fish bone (Bellwood et al. 1998). Because there are "no good taphonomic reasons" (Szabó and Amesbury 2011:12) for the absence of bone below the 8-ka level, the wallaby and phalanger have been argued to be human introductions to Gebe in the Holocene. However, the cuscus is apparently endemic to Gebe, and the absence of any bone whatsoever in the Pleistocene levels makes it difficult to test whether the wallaby is indeed a translocation (P. Piper, personal communication, February 2015). If preservation were not an issue, it would be expected that some bones of endemic species would occur in the Pleistocene deposit, and perhaps changes in site function provide a better explanation for the absence of bone in the Pleistocene layers at Golo. The terminal Pleistocene horizon, just below the first appearance of vertebrate fauna, is said to contain circular and semicircular coral stone arrangements containing volcanic pebbles, the latter transported to the cave from the southern part of the island, which suggests a ritual use of the cave at this time (Bellwood et al. 1998:252). Golo also contains large numbers of coral cooking stones, and the marine shell is reportedly heavily burnt (Bellwood et al. 1998:252). It is possible that this area of the site had a specialized function for cooking vegetable foods. This could perhaps be resolved by micromorphological work on the sed-

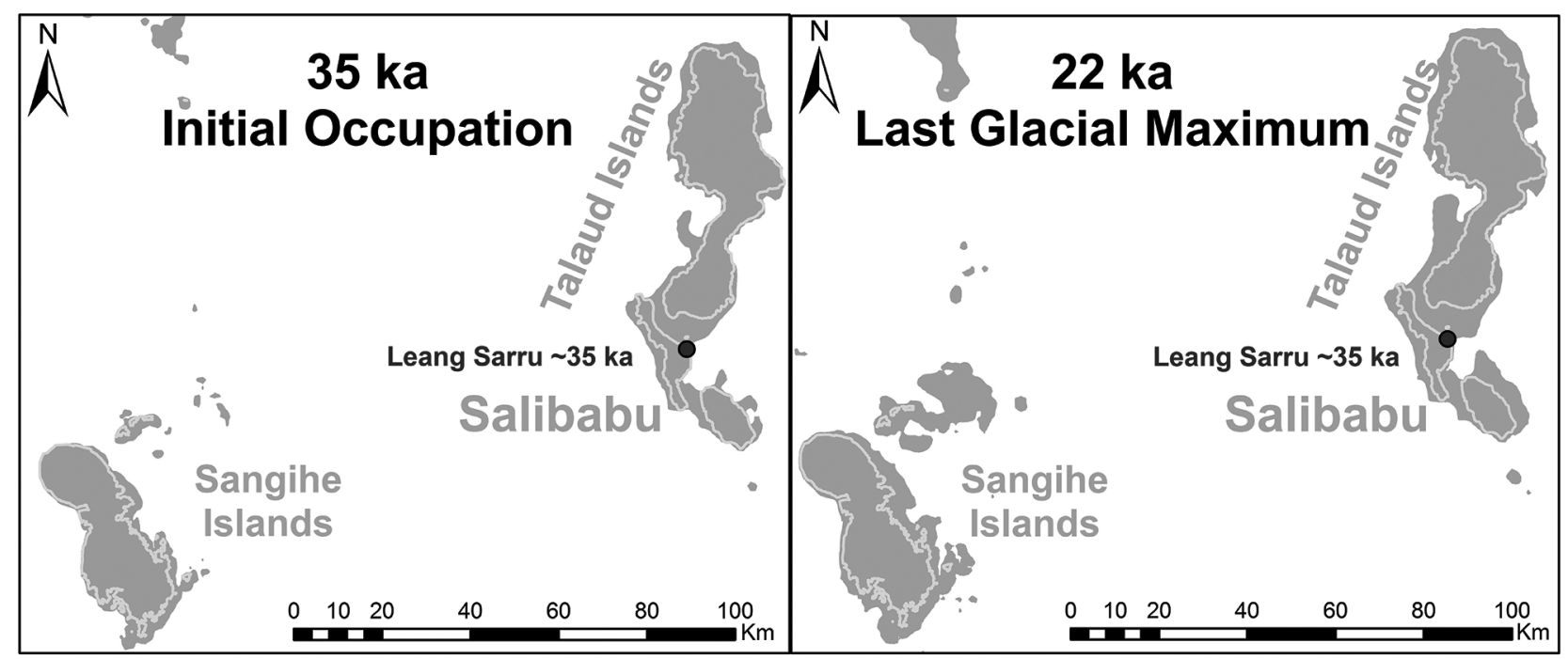

Figure 4. Reconstructions of the Talaud and Sangihe island archipelagos at the time of the first known occupation ( 35 ka at Leang Sarru) and during the peak of the last glacial maximum ( 22 ka). Reconstructed using the uplift-adjusted sea level curve from figure 2 and the General Bathymetric Chart of the Oceans bathometry chart (Smith and Sandwell 1997). A color version of this figure is available online. 


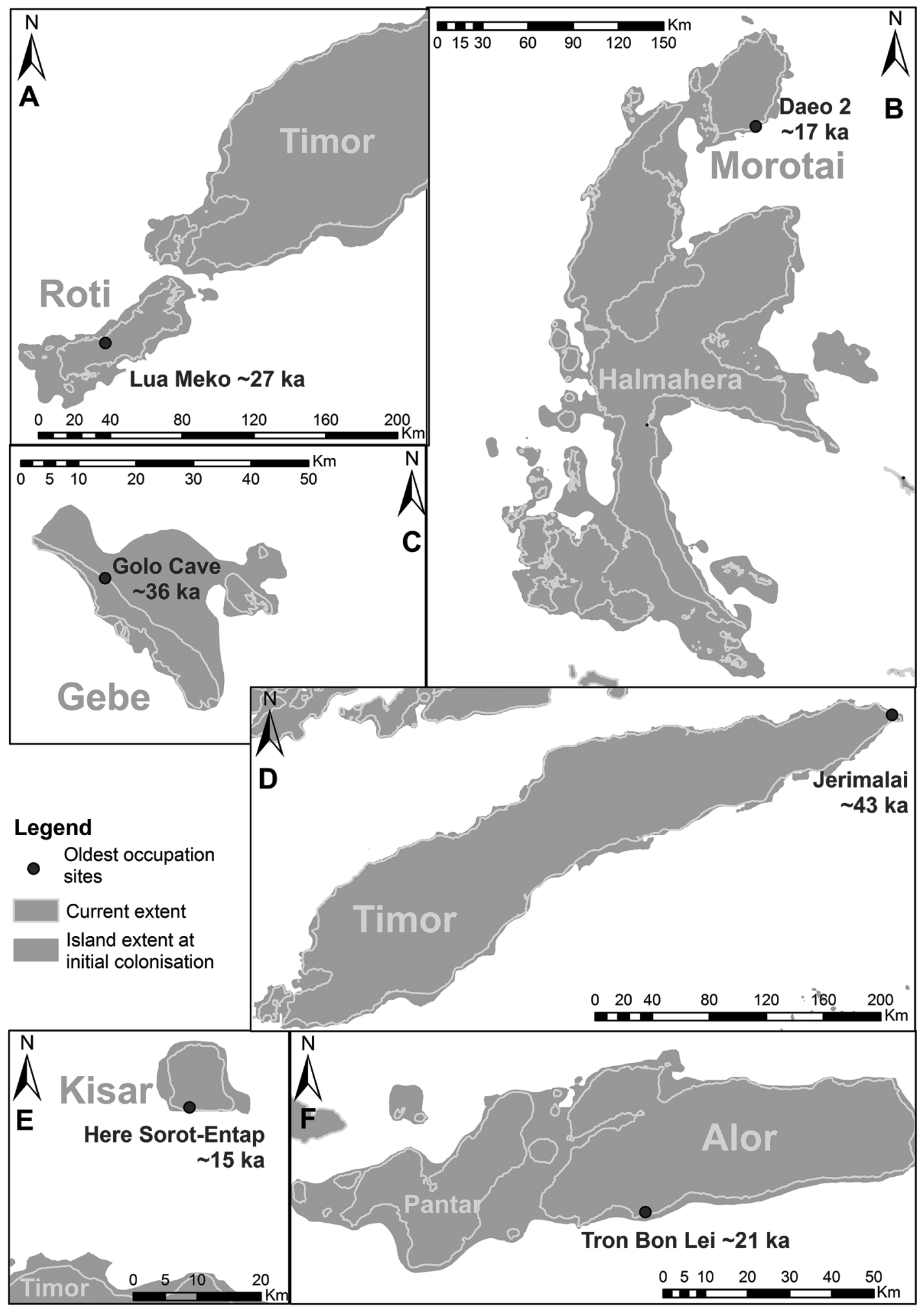

Figure 5. Reconstructions of island size at the time of first known occupation for Roti $(A)$, Morotai $(B)$, Gebe $(C)$, Timor $(D)$, Kisar $(E)$, and Alor $(F)$ islands. Reconstructed using the uplift-adjusted sea level curve from figure 2 and the General Bathymetric Chart of the Oceans bathometry chart (Smith and Sandwell 1997). A color version of this figure is available online. 
iments. Siti Nafisah Cave in Halmahera also has Dorcopis, along with an unknown bandicoot species, in layers dating to the mid-Holocene, but by the Late Holocene, both had become extinct (table 1; Bellwood et al. 1998:253).

Daeo 2 Cave in Morotai to the north in Halmahera was first occupied $\sim 17 \mathrm{ka}$ (table 1; Bellwood et al. 1998) and, at this time, was connected to Halmahera, Bacan, and other smaller surrounding islands (fig. 5). This combined land area would have been approximately $39,422 \mathrm{~km}^{2}$ (using an average $0.5 \mathrm{~m} / \mathrm{kyr}$ uplift) to $40,161 \mathrm{~km}^{2}$ (without uplift). Interestingly, despite relatively good faunal preservation down to the Pleistocene units, Daeo 2 has no evidence of the extinct Dorcopsis or bandicoots found in Gebe and Halmahera, but it does have a cuscus, murids (including one large species), and quantities of fish bone, the latter being most abundant in the Holocene units (Bellwood et al. 1998:246). Bellwood et al. conclude that, because Morotai is visible from and close to Halmahera, and these marsupials are absent, it would seem that initial colonization was followed by a long period of relative isolation (Bellwood et al. 1998:246-247). The absence of Dorcopsis and bandicoot on Morotai at the time when Morotai and Halmahera were joined suggests that the marsupials were translocated to Halmahera, but they must have been introduced after the two islands were separated, perhaps in the mid-Holocene. Simple unretouched flakes made on locally available beach pebbles occur at Daeo 2, but the authors are not specific about technology or distribution within the site.

Timor, the largest island on the southern dispersal route (as defined by Birdsell 1977), has produced some of the earliest dates for modern human use of the Wallacean Archipelago. Jerimalai Shelter and Lena Hara Cave have sequences dating back to $\sim 42 \mathrm{ka}$ (see table 1; O’Connor 2007; O'Connor, Allen, and Hawkes 2010). These sites are formed in uplifted coralline terraces and are within a kilometer of today's coastline. Due to the steep bathymetric drop off in this region, the sites would always have been proximal to the coast. Rocky shore shellfish, fish, and marine turtle dominate the earliest Pleistocene levels of both sites. The Pleistocene levels of Jerimalai contain a large quantity of fish bone, and pelagic species form a significant component of the assemblage (O'Connor, Ono, and Clarkson 2011). In contrast, Matja Kuru 2 of comparable antiquity (O'Connor, Robertson, and Aplin 2014), but located about $6 \mathrm{~km}$ from the coast today, has a Pleistocene assemblage dominated by giant rats; reptiles, such as pythons, lizards, and freshwater turtle; and some bat and small murid that may not be of anthropogenic origin. Marine shell was recovered in the Pleistocene and Holocene levels, but quantities are small in comparison with Lene Hara and Jerimalai, and marine fish and sea turtle are poorly represented, no doubt due to the greater transport distance from the coastline to this site. The Timor lithic assemblages evidence the predominant use of good-quality chert to produce flakes from a range of cores that include multiplatform, single-platform, bidirectional, bipolar, and radial cores. At Jerimalai, the only assemblage yet studied in detail, retouched pieces occur in low numbers, and overall the assemblage shows remarkable conservatism over time (Marwick et al.
2016). Small numbers of very tiny obsidian flakes from an asyet-unknown source - but one thought likely to be external to Timor-were also identified in deposits dating predominantly to after $\sim 14 \mathrm{ka}$ (Reepmeyer, O'Connor, and Brockwell 2011). The Timor-Leste sites also contain a range of shell items, including fish hooks by at least $\sim 16 \mathrm{ka}$ (O'Connor, Ono, and Clarkson 2011) and decorative items that begin to be made immediately after first occupation; like the lithics, these change little through time (Langley and O'Connor 2016; Langley, O'Connor, and Piotto 2016).

The archaeological assemblage from an area on the southern coast of Alor Island, Tron Bon Lei, provides insights about human subsistence strategies north of Timor. Settlement as recorded by the deposit in this shelter first occurred at $\sim 21 \mathrm{ka}$ (table 1; Hawkins et al. 2017), at a time when sea levels were low and Alor Island was merged with neighboring Pantar, Pura, Marisa, Rusa, Ternate, and Treweng islands, forming a single island of between $3,862 \mathrm{~km}^{2}$ (estimated with an average $0.5 \mathrm{~m} / \mathrm{kyr}$ uplift; fig. 2) and 3,910 $\mathrm{km}^{2}$ (without uplift).

In one Tron Bon Lei shelter that is within a few hundred meters of the current coastline, a $1 \times 1$-m test pit yielded abundant marine shellfish and fish bone accumulations dated from 21 to $3 \mathrm{ka}$, along with stone artefacts manufactured from basalt, obsidian, and chert, which suggests a human population almost solely dependent on marine resources before the Neolithic (Hawkins et al. 2017; Samper Carro, Louys, and O'Connor 2017; Samper Carro et al. 2016). The faunal assemblage from the Late Pleistocene-early Holocene occupation levels contained over 40,000 fish bones, with differences observed in the quantity of remains, taxonomic representation, and prey size between the Late Pleistocene and early Holocene layers. The Pleistocene assemblages (dated from $21 \mathrm{ka}$ to $10 \mathrm{ka}$ ) had a larger number of faunal remains compared with more recent accumulations, which suggests resource depression or alternatively a decrease in occupation intensity of the shelter during the early Holocene (S. C. Samper Carro, personal observation). This is surprising in view of the fact that coastal resources would have been more accessible in the Holocene after the rise in sea level and stabilization of near-shore coastal environments, and this contrasts with the abundance of Holoceneaged archaeological evidence documented in other Southeast Asia island environments more generally (e.g., Mahirta 2009:50, 61). The Tron Bon Lei Pleistocene assemblage contains a larger percentage of carnivorous fish families relative to herbivores as well as a larger number of remains from families of pelagic species. Prey size is larger in the Pleistocene levels, reflecting the larger quantity of pelagic fishes compared with reef environment fishes (O'Connor et al., forthcoming $b$; Samper Carro et al. 2016). This likely represents changes in fishing practices and/or technology, whereby hook and lure fishing during the Pleistocene declined in importance relative to other capture methods, such as netting. The fish assemblage from Alor has strong similarities with the assemblage composition at both Jerimalai and Lene Hara in Timor-Leste, except turtle bone is not common in the Alor deposits. In terms of nonvertebrate fauna, the 
Tron Bon Lei pit B assemblage has a dense and well-preserved shell midden throughout the Pleistocene and early- to midHolocene levels. Interestingly, the Pleistocene levels are dominated by an arthropod: a large barnacle; there are kilograms of this barnacle in some of the Pleistocene excavation units. In terms of molluscs, rocky substrate marine species predominate and include limpets and false limpets (Fissurellidae; Cellana and Patella species), abalone (Haliotis species), Chitonidae, and $\mathrm{Ne}-$ ritidae. Turbo species, Tectus species, Soccostrea, Tridacna species, Hippopus species, Thiaridae, Muricidae, and Stombus species are also represented, and there are very small contributions from freshwater taxa. Crabs and urchins were recovered from all excavation units in variable quantities (O'Connor, personal observation).

Analysis of the stone artefacts from this site is in progress, but like Jerimalai, the assemblage comprises cores, flakes, and low numbers of flake tools with no formal patterning. The obsidian artefacts have been identified as having distinct geochemical signatures indicating three separate source locations (Reepmeyer et al. 2016). One of the obsidians is a geochemical match for the high-silicate obsidian in the Timor-Leste sites and, interestingly, appears in Tron Bon Lei at about the same time, $14 \mathrm{ka}$. While the source for this obsidian is not yet known, the small size of the artefacts made on it, the absence of artefacts with cortex, and the late appearance of this obsidian in the sequence combine to suggest that the source is not in Alor and instead suggest its maritime transport from elsewhere in the Sunda arc to Timor and Alor (Reepmeyer et al. 2016).

The tiny island of Kisar to the northeast of Timor is only approximately $10 \mathrm{~km} \times 8.7 \mathrm{~km}$ with a total area of $81.15 \mathrm{~km}^{2}$. It has a narrow coastal platform owing to its rapid rate of uplift and deep offshore profile. While it would have been slightly larger during periods of low sea level, it would never have been much larger than it is today. Our recent excavation at a shelter on the south coast, Here Sorot Entapa, demonstrates that the island was occupied by at least $15 \mathrm{ka}$. Based on a small testing in 2015 of two $1 \times 1-\mathrm{m}$ excavations (pits A and B), the site was first occupied at 13,176 $\pm 30 \mathrm{WK}-43325(15,091-15,338 \mathrm{cal}$ $\mathrm{BP}$; marine shell). The occupation horizon at $15 \mathrm{ka}$ is directly underlain by sterile coralline sands that are dated to $45,840 \pm$ 2,687 (WK-46537) on coral from a culturally sterile deposit. The coral date corresponds well with the estimated age for the uplift of the terrace in which the shelter is formed, demonstrating that it would have been available for habitation before $15 \mathrm{ka}$. The archaeological fauna in both test pits is overwhelmingly dominated by fish, shellfish, urchin, and crab. Aside from marine resources, these shelters contain only occasional bones of endemic small rodents, shrews, bats, small lizards, and snakes. Analysis of the lithics has not yet begun; however, as in the other Wallacean sites, the assemblage appears to be composed of cores, flakes, and low numbers of irregularly retouched flakes.

Roti Island immediately east of Timor was also occupied in the Pleistocene. Lua Meko Cave, near the north coast, has a lower nonbasal age of $\sim 28 \mathrm{ka}$ cal BP $(24,420 \pm 250$ ANU10908 ) associated with sparse stone artefacts and marine shell (table 1; Mahirta 2009:52). Roti was not connected to Timor at this time; however, the water crossing separating the two islands at this time would have been between $3.04 \mathrm{~km}$ (without uplift) and $3.52 \mathrm{~km}$ (with use of an average $0.5 \mathrm{~m} / \mathrm{kyr}$ uplift). Vertebrate faunal remains occur in the older Pleistocene units of Lua Meko but are fragmentary, heavily encrusted in carbonate, and not identifiable to taxon, so discussing subsistence is challenging. Based on the internal structure, most of the bone fragments in this lower unit are probably marine turtle. Marine shell in the lower Pleistocene levels included species from the families Chitonidae, Turbinidae, and Cypraeidae, which can be collected on rocky substrate or intertidal areas of the reef. The Holocene units see the appearance of mangrove mudflatand sandy substrate-associated shellfish as well as an overall increase in taxa from a broader range of habitats as sea levels rise and stabilize. Low numbers of stone artefacts occur in the earliest levels of Lua Meko and appear remarkably similar to those from Timor-Leste in that they evidence generalized reduction of chert to produce simple flakes but no specialized artefact forms (Mahirta 2009).

\section{Discussion}

On the basis of current data, it appears that Homo erectus, Homo floresiensis, and other non-sapiens hominins in the region made use of available terrestrial resources, particularly medium- to large-bodied fauna. No similar evidence of significant marine resource exploitation by these hominins exists. A scarcity of terrestrial faunal resources on the small islands east of Flores and Sulawesi, combined with an inability to develop and employ sophisticated fishing technologies, may have precluded successful dispersal by these hominins any farther east. Although unsuccessful dispersals to small islands (i.e., dispersals that did not produce a genetically viable population) are certainly possible or even likely, being unsuccessful, they would necessarily have been archaeologically short-lived, such that the chances of their discovery remain slim to nonexistent (e.g., Leppard and Runnells 2017).

Outside Flores, Luzon, and Sulawesi, conditions favorable for successful hominin colonization, based on island size and geological history, might have been present on the islands of Sumba and Timor. Sumba hosts at least one species of stegodon (Stegodon sumbaensis); however, its record is too poorly known, both archaeologically and palaeontologically, to speculate on further. Timor, on the other hand, has been explored extensively for archaeological deposits (e.g., Glover 1986; O'Connor 2007; O'Connor, Allen, and Hawkes 2010), and during the Pleistocene, it hosted two species of pygmy stegodons, a giant land turtle, and a Komodo dragon-sized lizard in the Late Pleistocene (Hooijer 1971). Although early claims were made for the association between stone tools and stegodon remains in Timor (e.g., Glover and Glover 1970; Maringer and Verhoeven 1975; Maringer and Verschuuren 1981), the idea that Pleistocene hominins other than Homo sapiens made it east of Flores is now discounted (Allen 1991; Jones and Spriggs 2002; O'Con- 
nor 2002). The subsistence constraints of pre-sapiens hominins may well explain this distribution. Certainly, direct movement of early hominins from Flores to Timor is possible; however, migration eastward through the islands of Lembata, Pantar, and Alor is more likely, because sea crossing distances are smaller (some of these islands were connected during glacial periods). Other than a giant $(\sim 2-\mathrm{kg})$ rat species, Alor Island hosts only small-bodied terrestrial endemics (Hawkins et al. 2017; Samper Carro et al. 2016). Lembata and Pantar have no Pleistocene prehistoric records, but Pantar's faunal history is likely to be similar to Alor's. Subsistence strategies of Pleistocene H. sapiens on the smaller Wallacean islands, such as Alor, appear to have required the exploitation of almost exclusively maritime resources (Samper Carro et al. 2016), strategies seemingly not employed by earlier hominins. The likely route to Timor would therefore have precluded hominins, which would explain their apparent absence from this large island.

Thus, independent of seafaring abilities, we suggest that the distribution of modern humans in Wallacea was dictated by the flexibility of subsistence strategies, without which continuous and successful survival on small islands with depauperate faunas was not possible. The suggestion that the dispersal of pre-sapiens Asian hominins was limited by subsistence strategy is clearly one that requires additional testing, and future research in the area should aim to fill the dearth of detailed zooarchaeological studies of Early and Middle Pleistocene hominin assemblages. Furthermore, with so few islands in the region that boast any kind of Pleistocene archaeological record, further exploration and fieldwork in the region may dramatically alter this model. As aptly demonstrated with the announcement of the discovery of $H$. floresiensis over a decade ago, the potential for unexpected discoveries in the region should not be underestimated.

All records indicate that $H$. sapiens that moved through the islands east of Huxley's Line were able to do so as a result of ecological flexibility and innovation, which allowed them to successfully subsist on the most depauperate of islands through the exploitation of almost purely marine resources. Whether the direct ancestors of the first modern human colonizers of Wallacea were already exploiting such resources, or whether such innovations in subsistence behavior occurred as a result of the unique environments present in Wallacea, is not answered by the archaeological records west or east of Huxley's Line. Nevertheless, on the basis of current records from the region, it appears that extensive and systematic marine exploitation was the purview of only $H$. sapiens and that this shift in subsistence strategy occurred concurrent with first arrival on all island groups.

Detailed zooarchaeological examinations of Late Pleistocene archaeological assemblages consistently indicate that $H$. sapiens relied almost exclusively on marine resources on small islands and coastal sites. Away from the coast, modern humans on the larger Wallacean islands took advantage of a range of small and medium-size murids, reptiles, bats, and birds. As sea levels rose and fell over the past 50,000 years, the Wallacean islands changed size. In some cases, islands that are adjacent today were joined together, creating larger land masses that were perhaps better suited to sustaining permanent human populations. Conversely, when sea levels were high, these islands were separate, as they are today, and they may have been used in a more transient fashion with groups making their livelihood by moving between small island groups to take advantage of shifting or seasonal resources (Ono, Soegondho, and Yoneda 2009; Tanudirjo 2001).

Most of the Wallacean sites lack skeletal remains in the earliest layers, and the stone artefact assemblages lack patterned, specialized, and curated tool production, such as retouched blades and backed artefact technologies that are typically associated with behaviorally modern humans in other regions of the world. However, the Pleistocene levels of Jerimalai, with its emphasis on pelagic fishing and shell artefact production, and the stone structures in Golo convincingly demonstrate modern humans to have been the occupants of these sites. It is likely that the development of specialized and curated technologies may have occurred in the face of specific or changing environmental conditions (Petraglia et al. 2009) and were simply not required in the islands of Wallacea, which did not experience major climatic oscillations during the human occupation timespan, and where maritime resources seem to have formed the mainstay of the diet before the Late Holocene $\sim 3.5 \mathrm{ka}$ (see also Szabó, Brumm, and Bellwood 2007). This hypothesis receives some support from the personal ornament repertoire made on marine shell in the Timor-Leste assemblages. These ornaments appear immediately after first settlement, perhaps indicating an early phase of experimentation and innovation following immediately on modern human entry into a new and unfamiliar environment. Once invented, however, these artefacts show remarkable conservatism over time in terms of form, raw material selection, manufacturing, and use wear (Langley and O'Connor 2016; Langley, O'Connor, and Piotto 2016).

Despite their maritime capabilities, there is no evidence for return voyaging after initial migration into Wallacea. Return voyaging might be seen in the human-assisted movement of animals or other resources, found to be absent in the islands after settlement, from the Asian mainland, from New Guinea, or from larger islands, such as Sulawesi. Human-assisted movement of faunal species would be one way of increasing available protein on the small islands with limited fauna. However, evidence that this strategy was pursued in the Pleistocene is scarce. The earliest-claimed translocation is from Laing Bawah, the cave adjoining Liang Bua in Flores, where a fragment of pig skull coated in carbonate was dated by U-Th to between 33 and $23 \mathrm{ka}$. Gagan et al. (2015:533) suggest that this indicates that Sus species "may have dispersed into Island Southeast Asia earlier than previously recognized." In the adjacent cave, Liang Bua, despite a well-stratified excavation spanning a period of $\sim 20 \mathrm{ka}$, van den Berg report the presence of Sulawesi warty pig, Sus celebensis, at only $7 \mathrm{ka}$ (van der Bergh et al. 2009b). All other introduced species at Liang Bua are associated with the Neolithic 
and the appearance of pottery. The potential translocation of Sus species in Flores at such an early date is very surprising in view of the fact that Sus species have not been reported elsewhere in the Wallacean islands until the Neolithic or more recently. There are no other records of Pleistocene faunal translocations into the Wallacean Archipelago.

Java is home to at least one species of endemic pig, Sus verrucosus, and Sulawesi hosts two endemic porcines (Corbet and Hill 1992). If the early occurrence for the pig in Flores is substantiated, it more likely represents an unusual (although by no means unique) colonization for a medium- to large-bodied placental east of Wallace's Line rather than a deliberate translocation by people. The Dorcopsis in Golo Cave on Gebe Island and at Siti Nafisah in Halmahera is likely to be a mid- to Late Holocene translocation, at least in Halmahera, in view of its absence in Daeo 2 Cave in Morotai (which was connected to Halmahera until the early Holocene). In Timor-Leste, the cuscus Phalanger orientalis was originally reported from $\sim 9.5 \mathrm{ka}$ on the basis of associated radiocarbon ages obtained on shellfish (O'Connor 2006). This specimen has now been directly dated to $\sim 3 \mathrm{ka}$ (O'Connor 2015). Our recent investigation of some of the smaller Wallacean islands has also found no evidence for species introductions until the Late Holocene. Alor and Kisar have no translocated fauna before the Neolithic (J. Louys, personal observation). If the introduction of exotic species stood to benefit human settlement anywhere, Kisar would seem to be a prime candidate. The evidence would suggest that modern humans did not need to take animal protein sources with them to successfully settle even the smallest islands east of Huxley's Line.

The earliest evidence for interisland transport of materials is the high-silicate obsidian artefacts found in the Timor-Leste coastal assemblages and in Tron Bon Lei in Alor after $\sim 14 \mathrm{ka}$ (Reepmeyer 2016). Although the source of this obsidian is currently unknown, it is likely to be on one of the volcanic islands of the Sunda arc to the east of Timor and Alor. The presence of this geochemically distinct obsidian demonstrates that regular interisland voyaging was occurring from this time, at least from the source island to Timor and Alor. In view of this, it is all the more surprising that no attempt was made to transport terrestrial fauna from the mainland or from the more faunally diverse islands in the archipelago.

Rather, it would seem that the maritime subsistence strategies honed in the Wallacean archipelago $>40$ ka were sufficient for the population sizes for tens of millennia after initial settlement. Resources such as plants must have been a mainstay of the diet, and a better understanding of their role should be a priority for future work. Perhaps most surprising of all is that, despite the unbalanced and depauperate terrestrial faunas on the islands of Wallacea, none of the Pleistocene faunal assemblages currently indicate that modern humans moving through the archipelago impacted ecosystems significantly as a result of clearance, firing, or direct predation. On the basis of current evidence, a human role in the extinction of stegodon on Timor has been argued as unlikely (Louys, O'Connor, and
Price 2016). Of the four genera of giant rats on Timor, all of which are extinct today, all survived from the time of human arrival until a few thousand years ago (Louys, Aplin, and O'Connor 2015). Similarly, Babyrusa and the Anoa species in Sulawesi are today under threat of extinction but are found throughout Pleistocene archaeological sites and through to the Late Holocene in some sites in Southeast Sulawesi (O'Connor et al., forthcoming $a$ ). The Dorcopsis wallaby on Gebe and Halmahera and the Halmahera bandicoot are also Late Holocene extinctions, perhaps casualties of Neolithic land clearance (Bellwood et al. 1998). Although few Pleistocene sequences have been studied in depth, those currently available show no firm evidence of over hunting or extinctions. Contrasting the history of Pleistocene and Holocene extinctions on oceanic islands should be made a priority for future research.

\section{Acknowledgments}

Sue O’Connor thanks Michael Petraglia, Christopher Bae, and Katerina Douka for the invitation to the Wenner-Gren Foundation symposium "Human Colonization of Asia in the Late Pleistocene" as well as Laurie Obbink for all of her assistance during the workshop. We acknowledge two anonymous reviewers whose comments significantly improved our article. This study was funded by an Australian Research Council Laureate project FL120100156 to Sue O’Connor.

\section{References Cited}

Allen, Harry. 1991. Stegodonts and the dating of stone tool assemblages in island Southeast Asia. Asian Perspectives 30(2):243-265.

Allen, Jim, and James F. O'Connell. 2008. Getting from Sunda to Sahul. In Islands of inquiry: colonisation, seafaring and the archaeology of maritime landscapes. Terra Australis 29. Geoffrey Clark, Foss Leach, and Sue O'Connor, eds. Pp. 31-46. Canberra: ANU E Press.

. 2003. The long and the short of it: archaeological approaches to determining when humans first colonised Australia and New Guinea. Australian Archaeology 57:5-19.

Anderson, Atholl. 2017. Ecological contingency accounts for earliest seagoing in the western Pacific Ocean. Journal of Island and Coastal Archaeology. doi:10.1080/15564894.2016.1277286.

Aubert, M., A. Brumm, M. Ramli, T. Sutikna, E. W. Saptomo, B. Hakim, M. J. Morwood, G. D. van den Bergh, L. Kinsley, and A. Dosseto. 2014. Pleistocene cave art from Sulawesi, Indonesia. Nature 514(7521):223-227.

Aziz, F., G. D. van den Bergh, M. J. Morwood, D. R. Hobbs, I. Kurniawan, J. Collins, and Jatmiko. 2009. Excavations at Tangi Talo, central Flores, Indonesia. In Pleistocene geology, palaeontology and archaeology of the Soa Basin, Central Flores, Indonesia. Pusat Survei Geologi, Badan Geologi Special Publication 36. . F. Aziz, M. J. Morwood, and G. D. van den Bergh, eds. Pp. 41-58. Bandung, Indonesia: Department of Energy and Mineral Resources.

Barker, Graeme. 2005. The archaeology of foraging and farming at Niah Cave, Sarawak. In The human use of caves in peninsula and island South-east Asia. Graeme Barker and David Gilbertson, eds. Special issue, Asian Perspectives 44(1):90-106.

Barker, Graeme, Huw Barton, Michael Bird, Patrick Daly, Ipoi Datan, Alan Dykes, Lucy Farr, et al. 2007. The 'human revolution' in lowland tropical Southeast Asia: the antiquity and behaviour of anatomically modern humans at Niah Cave (Sarawak, Borneo). Journal of Human Evolution 52(3):243261.

Barton, Huw. 2005. The case for rainforest foragers: the starch record at Niah Cave, Sarawak. In The human use of caves in peninsula and island South- 
east Asia. Graeme Barker and David Gilbertson, eds. Special issue, Asian Perspectives 44(1):56-72.

Barton, Huw, Victor Paz, and Anna Jane Carlos. 2017. Plant food remains from the Niah Caves: macroscopic and microscopic approaches. In Archae ological investigations in the Niah Caves, Sarawak. G. Barker and L. Farr, eds. Pp. 455-468. Oxford: McDonald Institute for Archaeological Research.

Bellwood, P., G. Nitihaminoto, G. Irwin, A. W. Gunadi, and D. Tanudirjo. 1998. 35,000 years of prehistory in the Northern Moluccas. In Bird's head approaches: Irian Jaya studies, a programme for interdisciplinary research. Gert-Jan Bartstra, ed. Pp. 233-275. Rotterdam: Balkema

Birdsell, Joseph. 1977. The recalibration of a paradigm for the first peopling of greater Australia. In Sunda and Sahul: prehistoric studies in Southeast Asia, Melanesia, and Australia. J. Allen, J. Golson, and R. Jones, eds. Pp. 113-167. London: Academic Press.

Boaz, Noel T., Russell L. Ciochon, Qinqi Xu, and Jinyi Liu. 2004. Mapping and taphonomic analysis of the Homo erectus loci at Locality 1 Zhoukoudian, China. Journal of Human Evolution 46(5):519-549.

Bouteaux, Anne, and Anne-Marie Moigne. 2010. New taphonomical approaches: the Javanese Pleistocene open-air sites (Sangiran, central Java). Quaternary International 223-224:220-225.

Bouteaux, Anne, Anne-Marie Moigne, François Sémah, and Teuku Jacob. 2007. Les assemblages fauniques associés aux sites à Homo erectus du dôme de Sangiran (Pléistocène moyen, Java, Indonésie). Comptes Rendus Palevol 6 (3):169-179.

Brumm, Adam, Gitte M. Jensen, Gert D. van den Bergh, Michael J. Morwood, Iwan Kurniawan, Fachroel Aziz, and Michael Storey. 2010. Hominins on Flores, Indonesia, by one million years ago. Nature 464(7289):748-752.

Brumm, Adam, Gerrit D. van den Bergh, Michael Storey, Iwan Kurniawan, Brent V. Alloway, Ruly Setiawan, Erick Setiyabudi, et al. 2016. Age and context of the oldest known hominin fossils from Flores. Nature 534(7606):249253.

Chappell, J. 1993. Late Pleistocene coasts and human migrations in the Austral region. In A community of culture: the people and prehistory of the Pacific. Matthew Spriggs, Douglas E. Yen, Wal Ambrose, Rhys Jones, Alan Thorne, and Ann Andrews, eds. Pp. 43-48. Canberra: Department of Prehistory, Australian National University.

Chappell, J., and H. H. Veeh. 1978. Late Quaternary tectonic movements and sea-level changes at Timor and Atauro Island. Geological Society of America Bulletin 89(3):356-368.

Choi, Kildo, and Dubel Driwantoro. 2007. Shell tool use by early members of Homo erectus in Sangiran, central Java, Indonesia: cut mark evidence. Journal of Archaeological Science 34(1):48-58.

Corbet, G. B., and J. E. Hill. 1992. The mammals of the Indomalayan region: a systematic review. Oxford: Oxford University Press.

Cox, Nicole. 2009. Variable uplift from Quaternary folding along the northern coast of East Timor, based on U-series age determinations of coral terraces. PhD thesis, Brigham Young University, Provo, Utah.

Cranbrook, Earl of. 2000. Northern Borneo environments of the past 40,000 years: archaeozoological evidence. Sarawak Museum Journal 55(76):61109.

Dennell, Robin. 2015. 2.7 Myr-300,000 years ago in Asia. In Earth systems and environmental sciences. Pp. 1-16. Amsterdam: Elsevier. doi:10.1016/B978-0 -12-409548-9.09535-X.

- 2014. East Asia and human evolution from cradle of mankind to culde-sac. In Southern Asia, Australia and the search for human origins. Robin Dennell and Martin Porr, eds. Pp. 8-20. Cambridge: Cambridge University Press.

Dennell, Robin W., Julien Louys, Hannah J. O’Regan, David M. Wilkinson. 2014. The origins and persistence of Homo floresiensis on Flores: biogeographical and ecological perspectives. Quaternary Science Reviews 96:98107.

Domínguez-Rodrigo, M., H. T. Bunn, and J. Yravedra. 2014. A critical reevaluation of bone surface modification models for inferring fossil hominin and carnivore interactions through a multivariate approach: application to the FLK Zinj archaeofaunal assemblage (Olduvai Gorge; Tanzania). Quaternary International 322-323:32-43.

Erlandson, Jon M., and Todd J. Braje. 2015. Coasting out of Africa: the potential of mangrove forests and marine habitats to facilitate human coastal expansion via the southern dispersal route. Quaternary International 382:31-41.

Ferraro, Joseph V., Thomas W. Plummer, Briana L. Pobiner, James S. Oliver, Laura C. Bishop, David R. Braun, Peter W. Ditchfield, et al. 2013. Earliest archaeological evidence of persistent hominin carnivory. PLOS ONE 8(4) e62174
Flannery, T. F., P. Bellwood, J. P. White, T. Ennis, G. Irwin, K. Schubert, and S. Balasubramaniam. 1998. Mammals from Holocene archaeological deposits on Gebe and Morotai Islands, Northern Moluccas, Indonesia. Australian Mammalogy 20:391-400.

Flannery, T. F., and Boeadi. 1995. Systematic revision within the Phalanger ornatus complex (Phalangeridae: Marsupialia), with description of a new species and subspecies. Australian Mammalogy 18:35-44.

Gagan, Michael K., Linda K. Ayliffe, Garry K. Smith, John C. Hellstrom, Heather Scott-Gagan, Russell N. Drysdale, Neil Anderson, et al. 2015. Geoarchaeological finds below Laing Bua (Flores, Indonesia): a split level cave system for Homo floresiensis. Palaeogeography, Palaeoclimatology, Palaeoecology 440:533-550.

Gaudzinski, Sabine. 2004. Early hominin subsistence strategies in the Levant: taphonomic studies of the Plio-Pleistocene 'Ubeidiya Formation (Israel). In Human paleoecology in the Levantine corridor. Naama Goren-Inbar and John D. Speth, eds. Pp. 75-88. Oxford: Oxbow.

Glover, I. 1986. Archaeology in Eastern Timor, 1966-67. Terra Australis 11. Canberra: Department of Prehistory, Australian National University.

Glover I. C., and E. A. Glover. 1970. Pleistocene flaked stone tools from Flores and Timor. Mankind 7(3):188-190.

Groucutt, Huw, Michael D. Petraglia, Geoff Bailey, Eleanor M. L. Scerri, Ash Parton, Liane Clark-Balzan, Richard P. Jennings, et al. 2015. Rethinking the dispersal of Homo sapiens out of Africa. Evolutionary Anthropology 24(4): 149-164.

Grün, Rainer, Stephen Eggins, Leslie Kinsley, Hannah Moseley, and Malcolm Sambridge. 2014. Laser ablation U-series analysis of fossil bones and teeth. Palaeogeography, Palaeoclimatology, Palaeoecology 416:150-167.

Hantoro, W. S., P. A. Pirazzoli, C. Jouannic, H. Faure, C. T. Hoang, U. Radtke, C. Causse, M. Borel Best, R. Lafont, S. Bieda, and K. Lambeck. 1994. Quaternary uplifted coral reef terraces on Alor Island, East Indonesia. Coral Reefs 13:215-223.

Hawkins, Stuart, Sofia Samper Carro, Julien Louys, Ken Aplin, Sue O'Connor, and Mahirta. 2017. Human palaeoecological interactions and owl roosting at Tron Bon Lei, Alor Island, eastern Indonesia. Journal of Coastal and Island Archaeology:1-17. doi:10.1080/15564894.2017.1285834.

Higham, Tom, Lindsay Lloyd-Smith, Huw Barton, Fiona Brock, and Chris Turney. 2016. Radiocarbon dating. In Archaeological investigations in the Niah Caves, Sarawak. G. Barker and L. Farr, eds. Pp. 219-232. Oxford: McDonald Institute for Archaeological Research.

Hooijer, D. A. 1971. A giant land tortoise, Geochelone atlas (Falconer \& Caytley), from the Pleistocene of Timor I and II. Proceedings Koninklijk Nederlandsch Akadamie van Wetenschappen Series B 74(5):504-525.

Jones, Rhys, and Matthew Spriggs. 2002. Theatrum Oceani: themes and arguments concerning the prehistory of Australia and the Pacific. In Archaeology: the widening debate. B. Cunliffe, W. Davies, and C. Renfrew, eds. Pp. 245-294. Oxford: Oxford University Press.

Joordens, J. C. A., Francesco d'Errico, Frank P. Wesselingh, Stephen Munro, John de Vos, Jakob Wallinga, Christina Ankjærgaard, et al. 2015. Homo erectus at Trinil on Java used shells for tool production and engraving. Nature 518(7538):228-231.

Joordens, J. C. A., F. P. Wesselingh, J. de Vos, H. B. Vonhof, and D. Kroon. 2009. Relevance of aquatic environments for hominins: a case study from Trinil (Java, Indonesia). Journal of Human Evolution 57(6):656-671.

Jouannic, Christian, Chi-Trach Hoang, Wayoe Soepri Hantoro, and Robert M. Delinom. 1988. Uplift rate of coral reef terraces in the area of Kupang, West Timor: preliminary results. Palaeogeography, Palaeoclimatology, Palaeoecology 68:259-272.

Kaifu, Yousuke, Reiko T. Kono, Thomas Sutikna, Emanuel Wahyu Saptomo, and Rokus Due Awe. 2015. Unique dental morphology of Homo floresiensis and its evolutionary implications. PloS ONE 10(11):e0141614.

Kealy, Shimona, Julien Louys, and Sue O'Connor. 2016. Islands under the sea: a review of early modern human dispersal routes and migration hypotheses through Wallacea. Journal of Island and Coastal Archaeology. doi:10.1080 /15564894.2015.1119218.

. 2017. Reconstructing palaeogeography and inter-island visibility in the Wallacean archipelago during the likely period of Sahul colonization, 65-45,000 years ago. Archaeological Prospection 24(3):259-272.

Lambeck, Kurt, and John Chappell. 2001. Sea level change through the last glacial cycle. Science 292(5517):679-686.

Langley, Michelle, and Sue O'Connor. 2016. An enduring shell artefact tradition from Timor-Leste: oliva bead production from the Pleistocene to Late Holocene at Jerimalai, Lene Hara, and Matja Kuru 1 and 2. PLoS ONE 11(8): e0161071. 
Langley, Michelle, Sue O'Connor, and Elena Piotto. 2016. 42,000-year old worked nautilus shell from Jerimalai (Timor-Leste): evidence for early coasta adaptation in ISEA. Journal of Human Evolution 97:1-16. doi:10.1016/j.jhevol .2016.04.005

Larick, Roy, and Russell L. Ciochon. 2015. Early hominin biogeography in island Southeast Asia. Evolutionary Anthropology 24(5):185-213.

Lemorini, Cristina, Thomas W. Plummer, David R. Braun, Alyssa N. Crittenden, Peter W. Ditchfield, Laura C. Bishop, Fritz Hertel, J. S. Oliver, F. W. Marlowe, M. J. Shoeninger, and R. Potts. 2014. Old stones' song: use-wear experiments and analysis of the Oldowan quartz and quartzite assemblage from Kanjera South (Kenya). Journal of Human Evolution 72:10-25.

Leppard, T. P. 2015. Passive dispersal versus strategic dispersal in island colonization by hominins. Current Anthropology 56:590-595.

Leppard, T. P., and C. Runnells. 2017. Maritime hominin dispersals in the Pleistocene: advancing the debate. Antiquity 91(356):510-519. doi:10.15184 /aqy.2017.16.

Louys, J., M. Herrera, S. Hawkins, K. Aplin, C. Reepmeyer, F. Hopf, S. Donnellan, S. O'Connor, and D. Tanudirjo. Forthcoming. Neolithic dispersal implications of murids from Late Holocene archaeological and modern natural deposits in the Talaud Islands, northern Sulawesi. In The Archaeology of Sulawesi: from the Pleistocene to the historic period, an update. David Bulbeck, Sue O'Connor, and Juliet Meyer, eds. Canberra: ANU E Press.

Louys, J., Sue O'Connor, and Ken Aplin. 2015. Holocene extinction of Timor's endemic giant murid community, and implications for modern murid conservation on islands. Journal of Vertebrate Paleontology 2015:167-168.

Louys, J., Sue O'Connor, and Gilbert Price. 2016. Uranium-thorium dating of Pleistocene stegodon from Timor Island, East Nusa Tenggara. PeerJ 4:e1788.

Louys, J., Kenny J. Travouillon, Mina Bassarova, and Haowen Tong. 2009. The use of protected natural areas in palaeoecological analysis: assumptions, limitations and application. Journal of Archaeological Science 36(10):22742288.

Mahirta. 2009. Prehistoric human occupation on Rote and Sawu Islands, Nusa Tenggara Timur, Indonesia. BAR International Series 1935. Oxford: Archaeopress.

Major, Jonathan, Ron Harris, Hong-Wei Chiang, Nicole Cox, Chuan-Chou Shen, Stephen T. Nelson, Carolus Prasetyadi, and Arif Rianto. 2013. Quaternary hinterland evolution of the active Banda Arc: surface uplift and neotectonic deformation recorded by coral terraces at Kisar, Indonesia. Journal of Asian Earth Sciences 73:149-161.

Maringer, J., and T. Verhoeven. 1975. Die Oberflächenfunde von Marokoak auf Flores, Indonesien: ein weiterer altpaläolithischer Fundkomplex von Flores. Anthropos 70:97-104.

Maringer, J., and J. Verschuuren. 1981. Zum Paliiolithikum der insel Tirnor, Indonesien. Anthropos 76:584-588.

Marwick, Ben, Chris Clarkson, Sue O’Connor, and Sophie Collins. 2016. Early modern human lithic technology from Jerimalai, East Timor. Journal of Human Evolution 101:45-61.

Meijer, Hanneke J. M., Lars W. van den Hoek Ostende, Gert D. van den Bergh, and John de Vos. 2010. The fellowship of the Hobbit: the fauna surrounding Homo floresiensis. Journal of Biogeography 37:995-1006.

Mijares, Armand Salvador, Florent Détroit, Philip Piper, Rainer Grün, Peter Bellwood, Maxime Aubert, Guillaume Champion, Nida Cuevas, Alexandra De Leon, and Eusebio Dizon. 2010. New evidence for a 67,000-year-old human presence at Callao Cave, Luzon, Philippines. Journal of Human Evolution 59(1):123-132.

Moigne, Anne-Marie, Rokhus Due Awe, Francois Semah, and Anne-Marie Semah. 2004. The cervids from the Ngebung site ('Kabuh' series, Sangiran Dome, Central Java) and their biostratigraphical significance. In Quater nary research in Indonesia. Susan G. Keates and Juliette M. Pasveer, eds. Pp. 31-44. Modern Quaternary Research in Southeast Asia 18. Leiden, Neth erlands: Balkema.

Morwood, M., and Penny van Oosterzee. 2007. The discovery of the Hobbit. Sydney: Random House Australia.

Morwood, M. J., P. B. O’Sullivan, F. Aziz, and A. Raza. 1998. Fission-track ages of stone tools and fossils on the east Indonesian island of Flores. Nature 392 (6672):173-176.

Nexer, Maëlle, Christine Authemayou, Taylor Schildgen, Wahyoe S. Hantoro, Stéphane Molliex, Bernard Delcaillau, Kevin Pedoja, Laurent Husson, and Vincent Regard. 2015. Evaluation of morphometric proxies for uplift on sequences of coral reef terraces: a case study from Sumba Island (Indonesia). Geomorphology 241:145-159.

O'Connell, James F., and Jim Allen. 2007. Pre-LGM Sahul (Australia-New Guinea) and the archaeology of early modern humans. In Rethinking the human revolution: new behavioural and biological perspectives on the origin and dispersal of modern humans. Paul Millars, Katie Boyle, Ofer Bar-Yosef, and Chris Stringer, eds. Pp. 395-410. Cambridge: McDonald Institute for Archaeology Research.

. 2012. The restaurant at the end of the universe: modelling the colonisation of Sahul. Australian Archaeology 74:5-17.

O'Connell, James F., Jim Allen, and Kristen Hawkes. 2010. Pleistocene Sahul and the origins of seafaring. In The global origins and development of seafaring. Atholl Anderson, James H. Barrett, and Katherine V. Boyle, eds. Pp. 57-68. Cambridge: McDonald Institute for Archaeology Research.

O'Connor, Sue. 2002. Pleistocene Timor: further corrections, a reply to Bednarik. Australian Archaeology 54:46-51.

. 2006. Unpacking the island: Southeast Asian Neolithic cultural package and finding local complexity. In Uncovering Southeast Asia's past: selected papers from the tenth biennial conference of the European Association of Southeast Asian Archaeologists, the British Museum, London 14th-17th September 2004. E. A. Bacus, I. C. Glover, and V. C. Pigott, eds. Pp. 74-87. Singapore: NUS Press.

2007. New evidence from East Timor contributes to our understanding of earliest modern human colonisation east of the Sunda Shelf. Antiquity 81(313):523-535.

2015. Rethinking the Neolithic in island Southeast Asia, with particular reference to the archaeology of Timor-Leste and Sulawesi. Archipel 90:15-47.

O'Connor, Sue, Anthony Barham, Matthew Spriggs, Peter Veth, Ken Aplin, and Emma St. Pierre. 2010. Cave archaeology and sampling issues in the tropics: a case study from Lene Hara Cave, a 42,000-year-old occupation site in East Timor, island Southeast Asia. Australian Archaeology 71:29-40.

O'Connor, Sue, D. Bulbeck, P. J. Piper, F. Aziz, B. Marwick, F. Campos, J. Fenner, et al. Forthcoming $a$. The human occupation record of Gua Mo'o hono, Walandawe Region of southeast Sulawesi. In The Archaeology of Sulawesi: current research on the Pleistocene to the historic period. David Bulbeck, Sue O'Connor, and Juliet Meyer, eds. Canberra: ANU E Press.

O'Connor, Sue, and John Chappell. 2003. Colonisation and coastal subsistence in Australia and Papua New Guinea: different timing, different modes. In Pacific archaeology: assessments and prospects. Proceedings of the International Conference for the 50th anniversary of the first Lapita excavation (July 1952). C. Sand, ed. Pp. 17-32. Les Cahiers de l'Archéologie en NouvelleCalédonie 15. Nouméa, New Caledonia: Département Archéologie, Service des Musées et du Patrimoine de Nouvelle-Calédonie.

O'Connor, Sue, Mahirta, Sofia C. Samper Carro, Stuart Hawkins, Shimona Kealy, Julien Louys, and Rachel Wood. Forthcoming $b$. Fishing in life and death: Pleistocene fish-hooks from a burial context in Alor Island, Indonesia. Antiquity.

O'Connor, Sue, Rintaro Ono, and Chris Clarkson. 2011. Pelagic fishing at 42,000 years before the present and the maritime skills of modern humans. Science 334(6059):1117-1121.

O'Connor, Sue, G. Robertson, and K. P. Aplin. 2014. Are osseous artefacts a window to perishable material culture? implications of an unusually complex bone tool from the Late Pleistocene of East Timor. Journal of Human Evolution 67:108-119.

Ono, Rintaro, Santoso Soegondho, and Minoru Yoneda. 2009. Changing marine exploitation during Late Pleistocene in Northern Wallacea: shell remains from Leang Sarru Rockshelter in Talaud Islands. Asian Perspectives 48(2):318-341.

O’Regan, H. J., A. Turner, L. C. Bishop, S. Elton, and A. L. Lamb. 2011. Hominins without fellow travellers? first appearances and inferred dispersals of Afro-Eurasian large-mammals in the Plio-Pleistocene. Quaternary Science Reviews 30(11):1343-1352.

Organista, Elia, Manuel Domínguez-Rodrigo, Charles P. Egeland, David Uribelarrea, Audax Mabulla, and Enrique Baquedano. 2016. Did Homo erectus kill a Pelorovis herd at BK (Olduvai Gorge)? a taphonomic study of BK5. Archaeological and Anthropological Sciences 8(3):601-624. doi:10.1007 /s12520-015-0241-8.

Parkinson, Jennifer Ann. 2013. A GIS image analysis approach to documenting Oldowan hominin carcass acquisition: evidence from Kanjera South, FLK Zinj, and neotaphonomic models of carnivore bone destruction. PhD dissertation, City University of New York, New York.

Pawlik, Alfred F., Philip J. Piper, Rachel E. Wood, Kristine Kate A. Lim, Marie Grace Pamela G. Faylona, Armand Salvador B. Mijares, and Martin Porr. 2015. Shell tool technology in island Southeast Asia: an early Middle Holocene Tridacna adze from Ilin Island, Mindoro, Philippines. Antiquity 89 (344):292-308. 
Paz, Victor. 2005. Rock shelters, caves, and archaeobotony in island Southeast Asia. In The human use of caves in peninsular and island Southeast Asia. Graeme Barker and David Gilbertson, eds. Special issue, Asian Perspectives 44(1):107-18.

Petraglia, M., C. Clarkson, N. Boivin, M. Haslam, R. Korisettar, G. Chaubey, P. Ditchfield, D. Fuller, H. James, and S. Jones. 2009. Population increase and environmental deterioration correspond with microlithic innovations in South Asia ca. 35,000 years ago. Proceedings of the National Academy of Sciences of the USA 106:12261-12266.

Piper, P. J., and A. S. B. Mijares. 2007. A preliminary report on a Late Pleistocene animal bone assemblage from Callao Cave, Peñablanca, Northern Luzon, Philippines. Quezon City: Archaeological Studies Program, University of the Philippines.

Piper, P.J., and R. Rabett. 2017. Vertebrate fauna from the Niah Caves. In Archaeological investigations in the Niah Caves, Sarawak. G. Barker and L. Farr, eds. Pp. 401-437. Oxford: McDonald Institute for Archaeological Research.

Pirazzoli, P. A., U. Radtke, W. S. Hantoro, C. Jouannic, C. T. Hoang, C. Causse, and M. B. Best. 1993. A one million-year-long sequence of marine terraces on Sumba Island, Indonesia. Marine Geology 109:221-236.

Plummer, Thomas. 2004. Flaked stones and old bones: biological and cultural evolution at the dawn of technology. Physical Anthropology 125(39):118164.

Reepmeyer, Christian, Sue O'Connor, and Sally Brockwell. 2011. Long-term obsidian use at the Jerimalai rock shelter in East Timor. Archaeology in Oceania 46:85-90.

Reepmeyer, Christian, Sue O'Connor, Mahirta, Tim Maloney, and Shimona Kealy. 2016. Late Pleistocene/early Holocene maritime interaction in Southeastern Indonesia-Timor Leste. Journal of Archaeological Science 76: 21-30.

Reyes-Centeno, Hugo, Silvia Ghirotto, Florent Détroit, Dominiques GrimaudHervé, Guido Barbujani, and Katerina Harvati. 2014. Genomic and cranial phenotype data support multiple modern human dispersals from Africa and a southern route into Asia. Proceedings of the National Academy of Sciences of the USA 111(20):7248-7253.

Robles, Emil, Philip Piper, Janine Ochoa, Helen Lewis, Victor Paz, and Wilfredo Ronquillo. 2015. Late Quaternary sea-level changes and the palaeohistory of Palawan Island, Philippines. Journal of Island and Coastal Archaeology 10(1):76-96.

Samper Carro, Sofia C., Julien Louys, and Sue O'Connor. 2017. Methodological considerations for icthyoarchaeology from the Tron Bon Lei se quence, Alor, Indonesia. Archaeological Research in Asia. doi:10.1016 /j.ara.2017.09.006.

Samper Carro, Sofia C., Sue O'Connor, Julien Louys, Stuart Hawkins, and Mahirta. 2016. Human maritime subsistence strategies in the Lesser Sunda Islands during the terminal Pleistocene-early Holocene: new evidence from Alor, Indonesia. Quaternary International 416:64-79. doi:10.1016/j.quaint 2015.07.068.

Schepartz, L. A., D. Bakken, S. Miller-Antonio, K. Paraso, P. Karkanas. 2003. Faunal approaches to formation processes at Panxian Dadong. In Current research in Chinese Pleistocene archaeology. C. Shen and S. G. Keates, eds. Pp. 70-94. Oxford: Oxford Archaeopress.

Schepartz, L. A., S. Stoutamire, and D. A. Bekken. 2005. Stegodon orientalis from Panxian Dadong, a Middle Pleistocene archaeological site in Guizhou, South China: taphonomy, population structure and evidence for human interactions. Quaternary International 126:271-282.

Semah, Francois, Hassane Saleki, and Christophe Falgueres. 2000. Did early man reach Java during the Late Pliocene? Journal of Archaeological Science 27:763-769.

Simons, Allison, and David Bulbeck. 2004. Late Quaternary faunal successions in South Sulawesi, Indonesia. In Quaternary research in Indonesia. Susan G. Keates and Juliette M. Pasveer, eds. Pp. 167-190. Modern Quaternary Research in Southeast Asia 18. Leiden, Netherlands: Balkema.
Smith, Walter H. F., and David T. Sandwell. 1997. Global sea floor topography from satellite altimetry and ship depth soundings. Science 277(5334):19561962.

Storm, Paul. 2012. A carnivorous niche for Java Man? a preliminary consideration of the abundance of fossils in Middle Pleistocene Java. Comptes Rendus Palevol 11(2-3):191-202.

Sumosusastro, P. A., H. D. Tjia, A. R. Fortuin, and J. Van Der Plicht. 1989. Quaternary reef record of differential uplift at Luwuk, Sulawesi East Arm, Indonesia. Netherlands Journal of Sea Research 24(2-3):277-285.

Sutikna, T., M. W. Tocheri, M. J. Morwood, E. W. Saptomo, R. D. Awe, S. Wasisto, K. Westaway, et al. 2016. Revised stratigraphy and chronology for Homo floresiensis at Liang Bua in Indonesia. Nature 532:366-369.

Szabó, Katherine, and Judith R. Amesbury. 2011. Molluscs in a world of islands: the use of shellfish as a food resource in the tropical island AsiaPacific region. Quaternary International 239(1-2):8-18.

Szabó, Katherine, Adam Brumm, and Peter Bellwood. 2007. Shell artefact production at 32,000-28,000 B.P. in island Southeast Asia: thinking across media? Current Anthropology 48(5):701-723.

Tanudirjo, Daud Aris. 2001. Islands in between: prehistory of the northeastern Indonesian archipelago. PhD thesis, Australian National University, Canberra.

van den Bergh, G., John de Vos, Paul Y. Sondaar, and Fachroel Aziz. 1996 Pleistocene zoogeographic evolution of Java (Indonesia) and glacio-eustatic sea level fluctuations: a background for the presence of Homo. Indo-Pacific Prehistory Association Bulletin 14:7-21.

van den Bergh, G. D., Y. Kaifu, I. Kurniawan, R. T. Kono, A. Brumm, E. Setiyabudi, F. Aziz, and M. J. Morwood. 2016a. Homo floresiensis-like fossils from the early Middle Pleistocene of Flores. Nature 534(7606):245-248.

van den Bergh, G. D., I. Kurniawan, M. J. Morwood, C. J. Lentfer, R. Setiawan Suyono, F. AzizSuyono, R. Setiawan, and F. Aziz. 2009a. Environmental reconstruction of the Middle Pleistocene archaeological/palaeontological site Mata Menge, Flores, Indonesia. In Pleistocene geology, palaeontology and archaeology of the Soa Basin, Central Flores, Indonesia. Fachroel Aziz, M. J. Morwood, and G. D. van den Bergh, eds. Pp. 59-94. Indonesia: Geological Survey Institute, Bandung.

van den Bergh, G., Bo Li, Adam Brumm, Rainer Grün, Dida Yurnaldi, Mark W. Moore, Iwan Kurniawan, et al. 2016b. Earliest hominin occupation of Sulawesi, Indonesia. Nature 529(7585):208-211.

van den Bergh, G. D., H. J. M. Meijer, Rokhus Due Awe, M. J. Morwood, K. Szabó, L. W. van den Hoek Ostende, T. Sutikna, E. W. Saptomo, P. J. Piper, and K. M. Dobney. 2009b. The Liang Bua faunal remains: a 95 k.yr. sequence from Flores, East Indonesia. Journal of Human Evolution 57(5):527-537.

van Heteren, Anneke H. 2012. The hominins of Flores: insular adaptations of the lower body. Comptes Rendus Palevol 11(2-3):169-179.

van Heteren, Anneke H., and John de Vos. 2007. Heterochrony as a typical island adaptation in Homo floresiensis. In Proceedings of the International Seminar on Southeast Asian Paleoanthropology: recent advances on Southeast Asian paleoanthropology and archaeology. Pp. 95-106. Indonesia: Faculty of Medicine, Gadja Mada University.

van Heteren, Anneke H., and A. R. Sankhyan. 2009. Hobbits and pygmies: trends in evolution. In Asian perspectives on human evolution. A. R. Sankhyan, ed. Pp. 172-187. New Delhi, India: Serial.

West, Jolee, and Julien Louys. 2007. Differentiating bamboo from stone tool cut marks in the zooarchaeological record, with a discussion on the use of bamboo knives. Journal of Archaeological Science 34(4):512-518.

Westaway, K. E., M. J. Morwood, R. G. Roberts, J. X. Zhao, T. Sutikna, E. W. Saptomo, and W. J. Rink. 2007. Establishing the time of initial human occupation of Liang Bua, western Flores, Indonesia. Quaternary Geochronology 2(1):337-343.

Zhang, Shuangquan, Fuyou Chen, Yue Zhang, Jingshu Li, Xiaoling Zhang, and Xing Gao. 2015. A taphonomic study on the skeletal remains of Cervus (Sika) grayi from layer 3 of the Peking man site at Zhoukoudian during the 2009-2010 field seasons. Quaternary International 400:36-46. doi:10.1016 /j.quaint.2015.09.081. 